Polgári Szemle, 15. évf. 1-3. szám, 2019, 15-45., DOI: 10.24307/psz.2019.0903

Matolcsy György

\title{
A sikeres válságkezelés a 12 gazdasági fordulat tükrében
}

\author{
Successful Crisis Management Against the \\ Background of Twelve Economic Breakthroughs
}

\section{Összefoglalás}

Immáron több mint egy évtizeddel a 2008-2009-es gazdasági világválságot követôen érdemes visszatekinteni a gazdaságtörténeti szempontból is meghatározó idôszak történéseire. A világgazdasági válság nyomán jelentkezô komplex kihívások és az arra adott válaszok ma is alapvetôen határozzák meg mindennapjainkat. Ráadásul - mint a történelem során már többször is - a gazdasági válság a közgazdaságtan mint tudományág fejlôdése kapcsán is kihívások elé állította a megelôzố évtizedekben uralkodó irányzatokat. A viták legelsô és talán legfontosabb sarokpontját a válságkezelés módja jelentette. A korábban meghatározó neoliberális gazdaságfilozófia szerint rövid távon a kereslet összehúzódását okozó kínálati reformok lehetnek üdvözítók, amelyekkel szemben egyre erôteljesebben jelentek meg a keynesi gazdaságösztönzést és a reformok terheit széles körben megosztani kívánó közgazdászok. Magyarország azon országok egyike, ahol ezen vita és annak következményei különösen látványosan megfigyelhetôk voltak. A válságot megelőzó hibás gazdaságpolitika következményeként a 2008/2009-es globális vihar Magyarországot rendkívül legyengült állapotban érte. Ennek, valamint a korábban meghatározó neoliberális alapokon nyugvó, elhibázott válságkezelés eredményeként 2010-ig Magyarország Európa egyik legsúlyosabb válságán ment át. A súlyos károkat követôen a 2010-ben hivatalba lépô polgári kormány új típusú válságkezelést hirdetett meg. Az innovatív, hagyományos és nem hagyományos lépésekkel egyaránt operáló, a gazdaságpolitikai ágak közötti összhangra építő stratégia sikeresen stabilizál-

Dr. Matolcsy György a Magyar Nemzeti Bank elnöke (matolcsygy@mnb.hu). 
Matolcsy György: A sikeres válságkezelés a 12 gazdasági fordulat tükrében

ta és újból felzárkózási pályára állította Magyarországot. Jelen tanulmány ezen válságkezelés legfontosabb lépéseirôl és eredményeiről nyújt átfogó képet.

Journal of Economic Literature (JEL) kódok: G01, E60, O47, E52

Kulcsszavak: gazdasági válság, gazdaságpolitika, gazdasági felzárkózás, monetáris politika

Summary

A decade after the 2008-2009 global economic crisis, it is worth looking back on the events of this key period in economic history. The complex challenges encountered in the wake of the global economic crisis and the responses given to them still determine our daily life. Moreover, just as several times during history, the economic crisis also posed challenges to the trends prevailing in economic thinking in the previous decades. The first, and perhaps most important, cornerstone of disputes concerned the method of crisis management. According to the previously predominant neoliberal economic philosophy, over the short term, supply reforms causing contraction in demand might bring redemption, but this view was increasingly opposed by the economists who wished to extensively share the Keynesian economy boosting method and the burdens of reforms. Hungary is one of the countries where this dispute and its consequences have been conspicuously observable. As a result of the incorrect economic policy followed before the economic crisis, Hungary had been depleted when she was hit by the 20082009 global thunderstorm. As a result of this condition and of the inappropriate crisis management based on the previously predominant neoliberal foundations, up to 2010 Hungary had undergone one of the most serious crises in Europe. After the gross damages, the government that took office in 2010 adopted a new kind of crisis management. This innovative strategy, which combined traditional and non-traditional steps and relied on agreement between the various economic policy areas, successfully stabilised Hungary and restored her on a convergence trajectory. This paper provides an overview of the most important steps and results of this crisis management.

Journal of Economic Literature (JEL) codes: G01, E60, O47, E52

Keywords: economic crisis, economic policy, closing the economic gap, monetary policy

\section{MAgYARORSZÁG A VÁLSÁGOT MEGELôZOó ÉVEKBEN}

Magyarországot a 2008-as globális pénzügyi válság rendkívül legyengült állapotban érte. Már jóval a válság elôtt komoly finanszírozási és strukturális problémák jelentkeztek. Az alapjaiban hibás, külsố eladósodásra építô 2002. évet követô gazdaságpolitika következtében a gazdaság legkülönbözóbb területein alakultak ki egyensúlytalanságok. Ezek hozzájárultak a magyar versenyképesség romlásához, a felzárkózás 
leállásához és a sérülékenység növekedéséhez. A magyar gazdaság potenciális növekedési üteme egyre inkább lemaradt az uniós és a visegrádi országokétól (Csehország, Lengyelország, Szlovákia), amihez egyaránt hozzájárult az alacsony foglalkoztatottság, a lassuló termelékenységnövekedés, illetve a beruházások nem elegendô szintje. A beruházási ráta - már jóval a válság előtt - 2005-től kezdődően mérséklődött, és érdemben elvált a régiós folyamatoktól. Az aktivitási és foglalkoztatási ráta az Európai Unióban az egyik legalacsonyabb volt. A válság eloott a rendkívül magas munkához kapcsolódó adók, illetve a túlzottan bókezú szociális rendszer mind keresleti, mind kínálati oldalon a munkapiac fejlódésének korlátját jelentette, akadályozva a gazdaság bóvülését.

Az óriásira duzzadó államháztartási hiányok mellett a folyó fizetési mérlegben is jelentôs hiány alakult ki. Elégséges belsố megtakarítások hiányában a magyar gazdaság a külsố eladósodás veszélyes pályájára állt, valamennyi gazdasági szereplő jelentôs mértékú - nagy arányban külföldi devizában denominált - adósságot halmozott fel. Az államháztartás a deficitet elsôsorban külsô forrásból finanszírozta, ami jelentôs megújítási és árfolyamkockázatot vont maga után amellett, hogy növelte a külsố adósságot. A helyzetet tovább fokozta, hogy az elérhetô belsố megtakarítások hiányában a hazai bankrendszer is egyre nagyobb mértékben hitelezett devizában, elsôsorban svájci frankban (Matolcsy, 2008).

A fiskális politika mellett a helyzetet a monetáris politikai döntések is súlyosbították. A magas külsô adósságot és ezáltal a forint gyengülését okozó hibás gazdaságpolitikai lépésekre reagálva, a jegybank 2003-ban 12,5 százalékra emelte az alapkamatot, ami historikus összehasonlításban különösen magasnak számított. Ezzel a lépéssel a jegybank meggátolta ugyan az árfolyam további gyengülését, azonban a hitelkamatok két számjegyúvé válása a termelô vállalatokkal szemben nehezen teljesíthetố megtérülési követelményeket támasztott. A mesterségesen erôsen tartott árfolyam ráadásul támogatta a devizahitelezés felfutását, így a gazdaság szereplôi egyre inkább devizahitelekkel helyettesítették a megdrágult forintforrásokat. A GDP-arányos hitelállomány a válság idejére 70 százalék fölé emelkedett, szerkezetében pedig egyre nagyobb arányt képviseltek a devizahitelek, ami a magánszektort megnövekedett árfolyamkockázatnak tette ki (Matolcsy, 2007).

\section{AZ ELSŐ VÁLASZLÉPÉSEK - HAGYOMÁNYOS RECEPT, SIKERTELEN VÁLSÁGKEZELÉS}

A válságot követô kockázatkerüló nemzetközi piaci hangulatban az euróval szembeni 230 forint szintrôl közel egy év leforgása alatt közel 40 százalékot gyengült a forint. Az árfolyam leértékelődése a magas devizakitettségen keresztül a háztartásokat különösen súlyosan érintette. Az árfolyam megemelkedése miatt a háztartások jövedelemarányos törlesztőrészletei drasztikusan megnövekedtek, miközben az államadósság finanszírozási lehetôségei beszúkültek. Ráadásul hazánkkal szemben 2004 óta túlzottdeficit-eljárás (EDP) is zajlott, mely további nehézséget jelentett a válságkezelés tekintetében. 


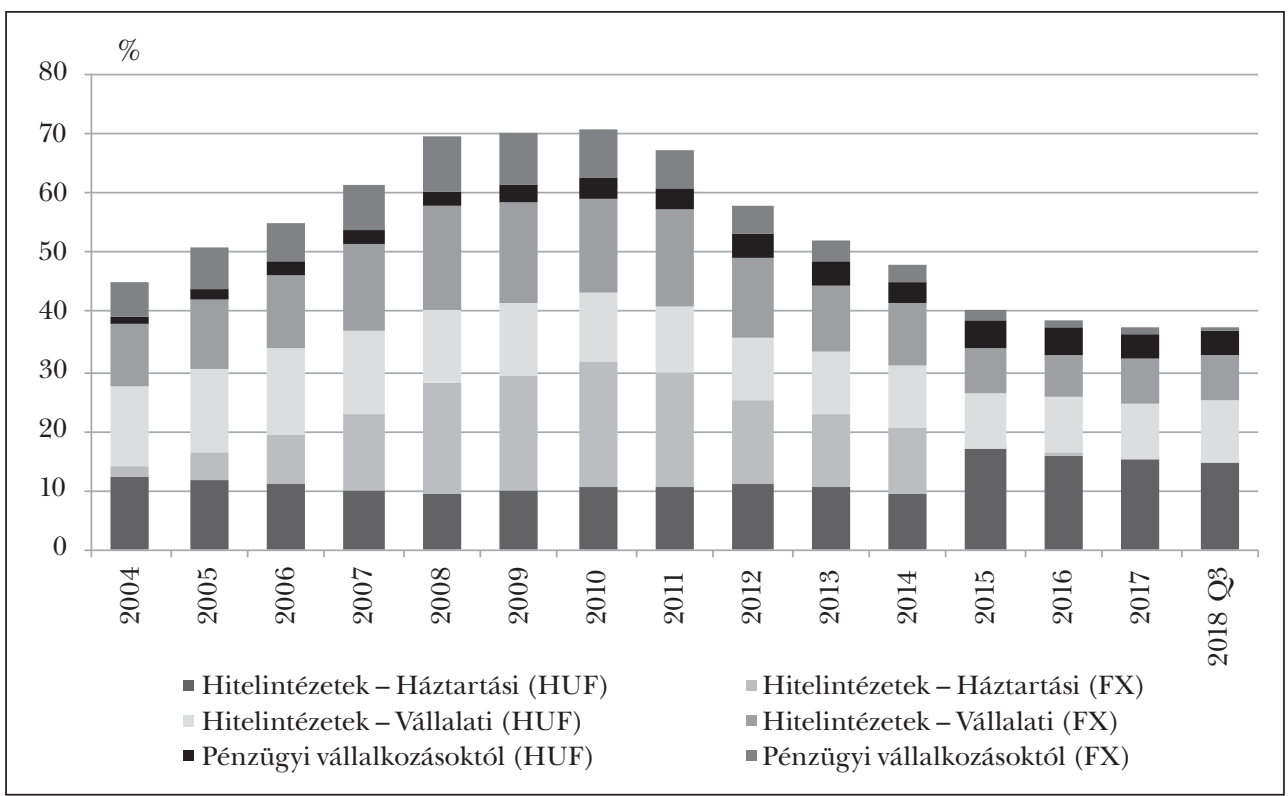

Forrás: $M N B$

Egyértelmúen költségvetési konszolidációra volt szükség, azonban a krízismenedzselést nehezítette a problémák hibás értékelése. Az intézkedések kizárólag a gazdaság kínálati oldalára koncentráltak, ami az egyébként is gyengélkedô aggregált kereslet további összehúzását, azaz megszorításokat jelentettek. A kiadási oldalra fókuszáló intézkedések azonban nem lehettek sikeresek, mert a költségvetési megszorításokat alkalmazók számottevôen alulbecsülték a fiskális multiplikátor - egységnyi kormányzati intézkedés növekedési hatása - nagyságát és annak recessziós környezetben fellépô pusztító erejét (Matolcsy, 2018). Hiába fogta vissza a kormány a költségvetési kiadásait, az ezzel párhuzamosan - sôt még nagyobb mértékben - csökkenô belsố kereslet következtében mérséklődô adóbevételek aláásták a költségvetési konszolidációt. Az eredmény az egyensúly kívánt helyreállítása helyett tovább mélyülố recesszió, növekvố munkanélküliség, töretlenül emelkedô adósságráták lettek. A klasszikus, megszorító intézkedésekre alapuló válságkezelés csak az újabb kiigazításoknak ágyazott meg.

A GDP 4-5 százalékának megfeleló 2009-es költségvetési megszorítás - amelyet a 2008 ószi IMF-Európai Bizottság mentôcsomag alapozott meg - legnagyobb vesztesei a háztartások lettek. Az általános áfakulcs emelése, a közszféra béreinek befagyasztása, a 13. havi jövedelem és a 13. havi nyugdíj megszüntetése, a nyugdíjindexálás megváltoztatása, a nyugdíjkorhatár emelése, a családi pótlék befagyasztása, a gyes és gyed feltételeinek szigorítása mind a háztartásokat sújtották, akik ugyanebben az időszakban szembesültek a devizahiteleikre fizetendô megemelkedett törlesztôrészletekkel is. A mérleg másik oldalán csak a munkát terhelő járulékok szerény csökkentése, illetve a minimálbér enyhe emelése szerepeltek. A megvalósuló intézkedések tovagyúrúzô hatá- 
saiból fakadóan nem az egyensúly felé vitték a gazdasági folyamatokat, hanem számottevố reálgazdasági áldozatokkal és magasan ragadó inflációval jártak (Matolcsy, 2015).

A megszorítások, illetve a bérhányad fokozatos csökkenésének következtében a lakossági fogyasztás és ezzel párhuzamosan a magyar kibocsátás is érdemben zsugorodott, amely tovább rontott az adósságmutatóinkon. Emellett a beruházások - az uniós források elérhetóségének ellenére - összességében a fogyasztásnál is nagyobb visszaesést szenvedtek el, melynek következtében hazánk potenciális növekedése tovább mérséklődött. Összességében a fiskális politika szerepe a válságkörnyezetben magas költségvetési multiplikátor miatt döntônek bizonyult a válság utáni visszaesésben (Matolcsy, 2018).

Elmaradt a teljes körú adóreform, ráadásul az idôzítés sem volt szerencsés, mivel Európa szintén válságkezelô üzemmódban múködött, így a külsố kereslet sem tudott hozzájárulni a költségvetés kiadási oldalán elért veszteségek ellensúlyozásához. A klaszszikus, megszorításokra alapuló krízismenedzsment ráadásul újabb problémákat is felszínre hozott. A kormányzó párt választói felhatalmazása számottevôen csökkent, ami politikai instabilitáshoz és kormányválsághoz vezetett. A finanszírozási és növekedési problémák politika válságba csaptak át, így idôvel a gazdaságpolitika társadalmi támogatottsága is hiányzott bármilyen reform megindításához. Egyensúlyi fordulat tehát csak egy, a hagyományos receptnek tekinthetố megszorításokon túllépó gazdaságpolitikával következhetett be, amire a 2010-es kormányváltás teremtett lehetôséget.

\section{TÖRTÉNELMI FORDULATOK A HAZAI GAZDASÁGPOLITIKÁBAN 2010 UTÁN}

A recessziók önmagukban nem csupán az aggregált kereslet visszaesését jelentik, de lehetôséget kínálnak a közgazdasági gondolkodás megújításának is. Újfajta, a (korábbi) fő́árammal szembehelyezkedô gondolatok is elôtérbe kerülhetnek, amelyek a krízismenedzsment módjával kapcsolatban is új gondolkodást indíthatnak el. 2010-ben a korábbi hibás válságkezelés következtében halmozott problémákkal nézett szembe a gazdaságpolitika. A feladat a pénzügyi stabilitás megteremtése és strukturális reformok egyidejú végrehajtása volt. A hatalomra kerülô kormányzat alapvetóen szakított a korábbi válságkezelési gyakorlattal. A gazdaság stabilizálása érdekében innovatív, célzott eszközök alkalmazásával nem csupán növekedésbarát intézkedéseket valósított meg, de ezzel egy időben a költségvetési egyenleget is javította (Matolcsy, 2014). A következőkben a 2010 óta megvalósuló legfontosabb gazdaságtörténeti fordulatokat vesszük górcsố alá.

\section{A költségvetés területén bekövetkezô fordulatok}

A magyarországi fiskális politikában az új, azóta már harmadik ciklusát töltô polgári kormány 2010-es hivatalba lépése hozta el a változást. A feladat nem ígérkezett egyszerûnek, egy idôben kellett stabilizálni a finanszírozási folyamatokat, miközben strukturális reformokkal meg kellett teremteni a gazdasági növekedés lehetôségét. 
Matolcsy György: A sikeres válságkezelés a 12 gazdasági fordulat tükrében

Adórendszer-fordulat

Az adórendszer átalakításának célja a költségvetési egyensúly biztosítása mellett a gazdasági növekedés támogatása volt. E kettôs cél egyidejư megvalósulásához szükséges volt a foglalkoztatás és a beruházások emelése, ami a leghatékonyabban a tôkét és munkát terhelố adók csökkentésével érhetố el. A 2010-ben elindított adóreform új filozófia keretében valósult meg. A legjelentôsebb változást az jelentette, hogy a munkát, illetve tôkét terhelô adók felól a kormányzat az indirekt adókra - fogyasztási, forgalmi típusú adók - helyezte a hangsúlyt. A munkára kivetett adó- és járulékterhek csökkentése, valamint az igénybe vehetố célzott kedvezmények (Munkahelyvédelmi akcióterv) kedvezốn hatottak a gazdasági szereplôk munkaerôpiaci döntéseire, növelve a munkavállalási hajlandóságot (Baksay-Palotai, 2017).

A munkát terheló adók mellett a tôkére kivetett közterhek jelentôsen torzítják a gazdasági szereplők beruházási döntéseit, így a széles körú konszenzus alapján a leginkább károsnak tekinthetô adóterhek közé tartoznak. A tôkét terhelő adók mértéke már 2010 második felétôl jelentôsen csökkent a társasági adó felsố kulcsához szükséges sáv 50-ról 500 millió forintra emelése következtében, aminek hatására kibóvült az alacsonyabb adókulcs alá tartozó kis- és középvállalatok köre. A társasági adó 2017-ben egykulcsossá alakult, és az egységes kulcs is 9 százalékra mérséklődött. A magyar kis- és középvállalati szektort érdemben támogatják a 2013-ban létrehozott új kisadózói cégformák (kata, kiva), amelyek igénybevételi létszáma a kedvezô adózási feltételeknek köszönhetốen napjainkig is dinamikusan bôvül. Az intézkedések következtében mérséklódött a hazai vállalatok adóterhelése, az adócsökkentések 2018-ra a GDP közel 2 százalékát jelenthetik (Baksay-Palotai, 2017).

A növekedésösztönzó adócsökkentések mellett az államháztartás egyensúlyának biztosításához szükséges volt olyan intézkedések bevezetése, amelyek pótlólagos forrást biztosítanak az adóreform végrehajtásához. A költségvetési források biztosítása nem jöhetett szóba hagyományos megszorító intézkedések alkalmazásával, mert azok éppen az adóreform gazdasági növekedésre gyakorolt kedvezó hatásait ásták volna alá. A kormányzat így inkább a terhek megosztására fókuszált. A fogyasztási-forgalmi típusú adónemek alkalmazása a reálgazdasági növekedés szempontjából kevésbé tekinthetô károsnak, mivel ezen adók nem térítik el jelentôsen a tôkeallokációs és munkaerôpiaci döntéseket. Az ágazati különadók emellett úgy képesek segíteni a költségvetés egyensúlyának fenntartását, hogy ezzel párhuzamosan méltányosabb és egyenlôbb közteherviseléshez vezetnek.

Az adóreformok fôsodrát elsôsorban az áfa felsô kulcsának 25 százalékról 27 százalékra növelése, a jövedéki adó mértékének többszöri emelése, valamint a szektorspecifikus adók átalakítása jelentette. A fogyasztási-, illetve forgalmiadó-bevételek jelentôs bôvüléséhez nemcsak a kulcsok emelése, hanem az adóalapok fokozatos szélesedése is hozzájárult, a különbözô változatos, újszerú gazdaságfehérítô lépések alkalmazásával. Ezen folyamatot meghatározta az online pénztárgépek, az elektronikus közúti áruforgalom-ellenốrzố rendszer (ekáer), valamint az online számlázás bevezetése és egyes területeken fordított áfakulcsok alkalmazása. A munkát terheló adókhoz hasonlóan a 
2. ábra: A 2010 óta végrehajtott adóváltozások kumulált statikus költségvetési hatása

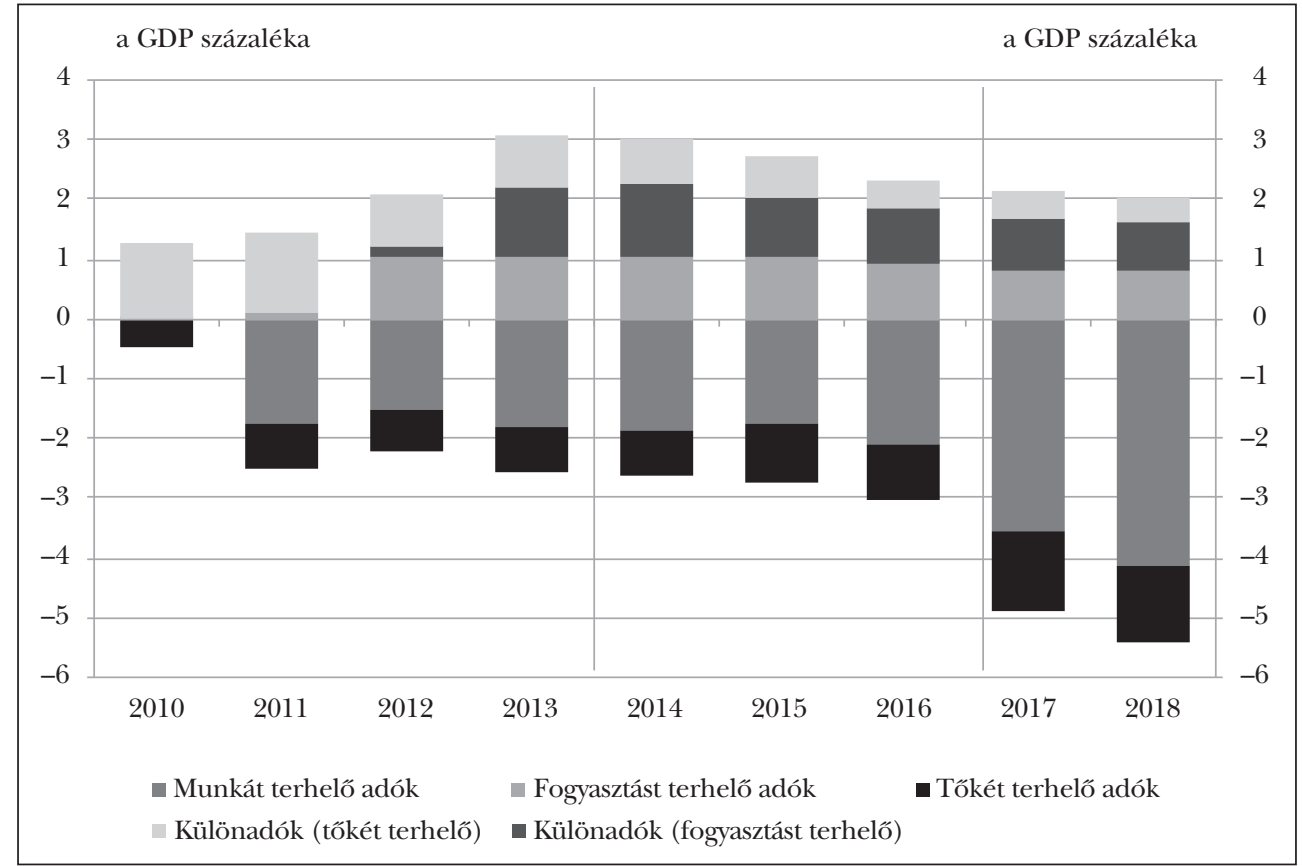

Forrás: Palotai, 2017

fogyasztási adók esetében is megfigyelhetố változás, hogy a gazdaságpolitika a célzott kedvezmények alkalmazását szorgalmazta, így csökkent egyes széleskörúen igénybe vett szolgáltatások (internet-, éttermi szolgáltatás) és alapvetô élelmiszerek árucsoportjainak (tej, tojás, baromfi-, hal-, sertéshús) áfakulcsa (Palotai, 2017).

A fogyasztási és forgalmi adók részesedésének növekedésében közrejátszott a különbözô különadók kivetése. Az adórendszer egészében megfigyelhetố átrendezôdés a szektorspecifikus válságadók között is lezajlott azáltal, hogy az egyes ágazatokat terhelô különadók 2013-at követôen fogyasztási-forgalmi különadókká alakultak át (pl. tranzakciós illeték, biztosítási adó, távközlési adó, népegészségügyi termékadó). A nagyobb közteherviseló képességgel és alacsonyabb effektív adókulccsal rendelkezô szolgáltató ágazatok (kiskereskedelem, pénzügyi-biztosítási szektor, energiaszektor, telekommunikáció) közterhei az elmúlt években fokozatosan mérséklódtek a költségvetési egyensúly fenntartásának figyelembevétele mellett.

\section{Motivációs fordulat}

A munkát terhelő adók csökkentése során az egyik legnagyobb változást a személyi jövedelemadó egykulcsossá alakítása jelentette. A 2011-tôl először 16 százalékra, majd 2016-tól újabb lépés eredményeként 15 százalékra csökkentett egyetlen kulcs alacsonyabb volt mindkét korábbi adókulcsnál, és a progresszivitás megszúnése támogatta 
a többletteljesítményt, a nagyobb munkaintenzitást, illetve a tudástőke felhalmozását. A marginális adóék az átalakítások után már 2013-ban a legtöbb kereseti kategóriánál a korábbi szintje alá mérséklódött, ami az azóta végrehajtott adó- és járulékcsökkentésekkel, valamint az igénybe vehetô jelentôs mértékú célzott kedvezmények (Munkahelyvédelmi akcióterv célcsoportjai és családi adókedvezmény) alkalmazásával még tovább csökkent (Matolcsy, 2016).

3. ábra: A hazai marginális adóék alakulása az átlagbér 67, 100 és 167 százalékánál

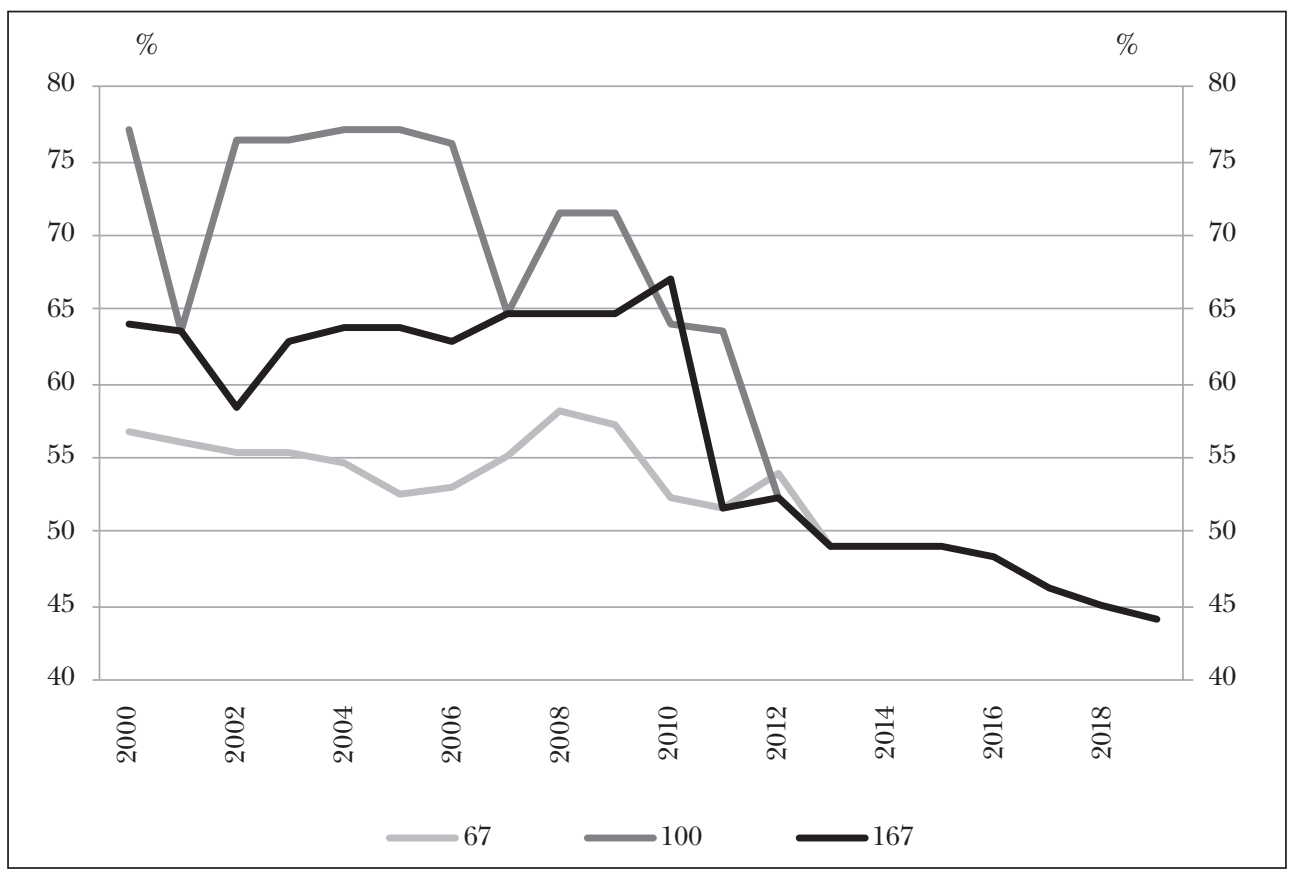

Forrás: $O E C D, M N B$

\section{Államháztartási fordulat}

A sikeresen végrehajtott költségvetési fordulat eredményeképpen 2012 óta a hiány stabilan a 3 százalékos maastrichti küszöb alatt alakul. Ennek a gazdaságtörténeti eredménynek az értékeléséhez érdemes felidézni, hogy a rendszerváltás után a magyar gazdaságpolitika egyszer sem volt képes 3 százalék alá csökkenteni a hiányt, és ezzel sikerült kikerülni a 2004-es EU-s csatlakozás óta folyamatosan fennálló túlzottdeficit-eljárás alól is (EDP). A végrehajtott költségvetési fordulatnak köszönhetôen egyszerre csökkent a hiány és indult meg a gazdasági növekedés (Matolcsy, 2016).

A Széll Kálmán-terv keretében több ütemben történt a korábban túlságosan laza, valójában a munkavállalás ellen ösztönzô szociális támogatási rendszer átalakítása. Egyes költségvetési kiadások zárolása mellett az önkormányzatok eladósodását is megfékezte a kormányzat új gazdaságpolitikája. 


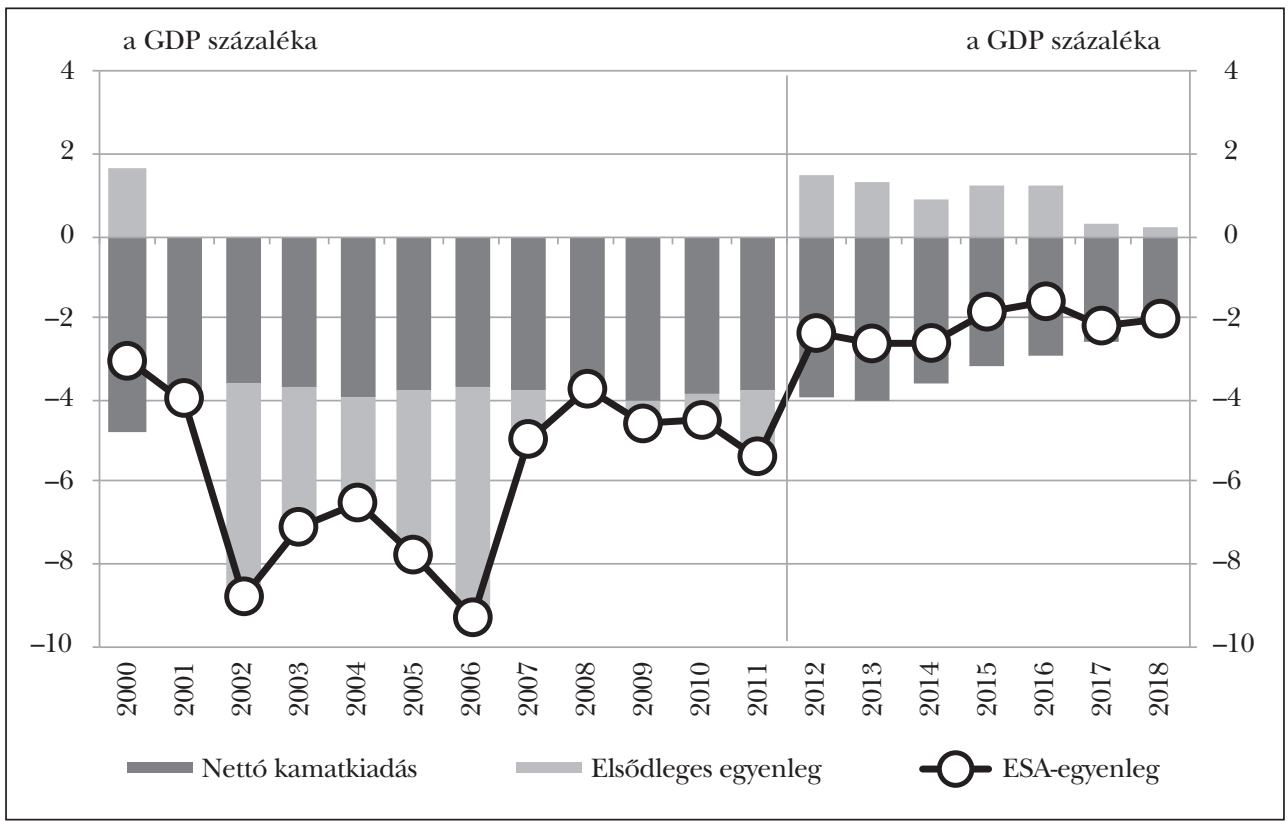

Megjegyzés: Az adatok a nyugdírendszer átalakítása miatt 2012-tôl jelentkezó imputált kamatkiadásokat nem tartalmazzák. A 2018. évi adat az MNB 2018. decemberi Inflációs jelentésében szerepló elōrejelzést mutatja.

Forrás: $\mathrm{KSH}, \mathrm{MNB}$

Kikerülés a túlzottdeficit-eljárás alól - EDP-fordulat

Magyarország az EU-hoz való csatlakozásának évétól kezdôdóen folyamatosan túlzottdeficit-eljárás alatt állt. A költségvetési egyenleg konszolidációját nemcsak a hatalmas eladósodottság, hanem az Európai Unió követelményeinek való megfelelés is indokolta. A szabály folyamatos áthágása a felzárkózást segítô kohéziós EU-forrásokat is veszélyeztette. Az államháztartási egyenleg javítása, valamint az EDP-ból való kikerülés a sérülékenységi faktorok csökkentése érdekében így elkerülhetetlenné vált.

A sikeres költségvetési fordulatnak köszönhetôen 9 év után, 2013-ban Magyarország kikerült a túlzottdeficit-eljárás alól. Elhárult az EU-források felfüggesztésével kapcsolatos gazdaságpolitikai veszély, és a sikeres új gazdaságpolitika eredményeit nemzetközi szinten sem lehetett tovább kétségbe vonni.

Államadósság-fordulat

A 2010 utáni gazdaságpolitika számára célként is megfogalmazódott a meredeken növekvố államadósság trendjének megtörése és csökkenô pályára állítása. A kormányzat e célját az adósságszabály létrehozásával, illetve annak Alaptörvénybe foglalásával 2011-ben alkotmányos szintre emelte. 
Matolcsy György: A sikeres válságkezelés a 12 gazdasági fordulat tükrében

5. ábra: Az egyes országokkal szemben indított túlzottdeficit-eljárások

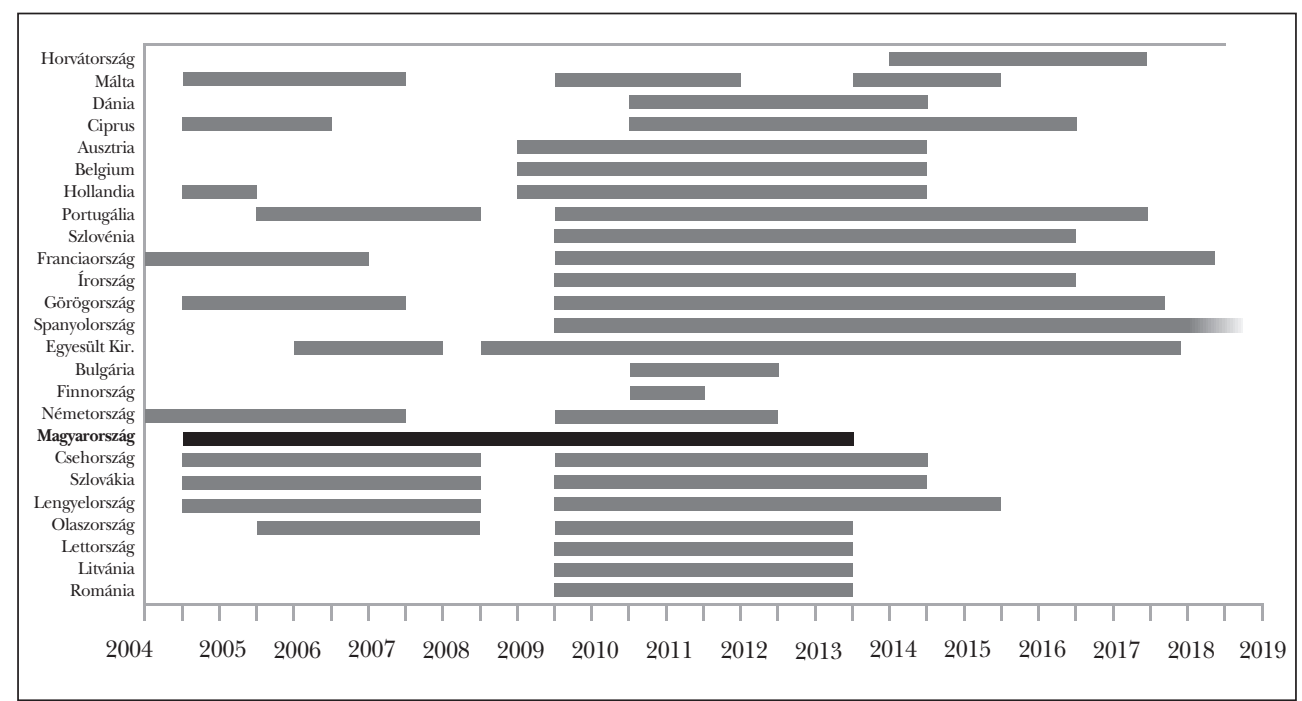

Forrás: Európai Bizottság

A költségvetési fordulat az államháztartási hiány fenntartható konszolidálásán és a gazdasági növekedés ösztönzésén keresztül lehetôvé tette az adósságráta csökkentését, amely a kormányzati lépések következtében stabilizálódott. A 2011-ben historikus csúcson álló, 80 százalék feletti adósságráta 2018 végére csaknem tíz százalékponttal mérséklődött, így Magyarország az egyetlen olyan gazdaság az Európai Unión belül, ahol 2012 óta minden évben folyamatosan csökkent a GDP-arányos bruttó államadósság. Ezzel párhuzamosan az államadósság devizaaránya is folyamatosan csökkent, ami jelentôsen mérsékelte Magyarország külsô sérülékenységét. A központi adósság devizaaránya 2011-ben az adósság csaknem felét tette ki, amely 2018-ra 20 százalék közelébe csökkent. A nagymértékú mérséklődéshez az EU- és IMF-hitelek teljes visszafizetése is hozzájárult. Hazánk javuló megítélését a kockázati felárak (CDS) és az állampapírpiaci hozamok mérséklődése mellett a nemzetközi hitelminôsítôk javuló besorolásai is visszaigazolták (Matolcsy, 2016).

Az elmúlt idôszakban jelentôsen javult az államadósság finanszírozási struktúrája is, amelyet a jegybank 2014 nyarán elindított Önfinanszírozási Programja (lásd késôbb) is támogatott a belföldi finanszírozás ösztönzésén keresztül.

\section{Munkaeröpiaci fordulat}

A 2008-ban kitört globális válsággal párhuzamosan a vállalatok munkaerôigénye érdemben mérséklődött, a foglalkoztatottak száma nagymértékben visszaesett. A 2010-et követô években a kormányzat számos - fóként a munkaerôpiaci részvétel emelkedését célzó - intézkedése hozzájárult a munkaerôpiac válságból való kilábalásához. Az idôskori és a rokkantnyugdíjazási feltételek szigorítása, valamint a nyugdíjkorhatár foko- 
6. ábra: Bruttó GDP-arányos államadósság és az adósság devizaarányának alakulása 2000-tól

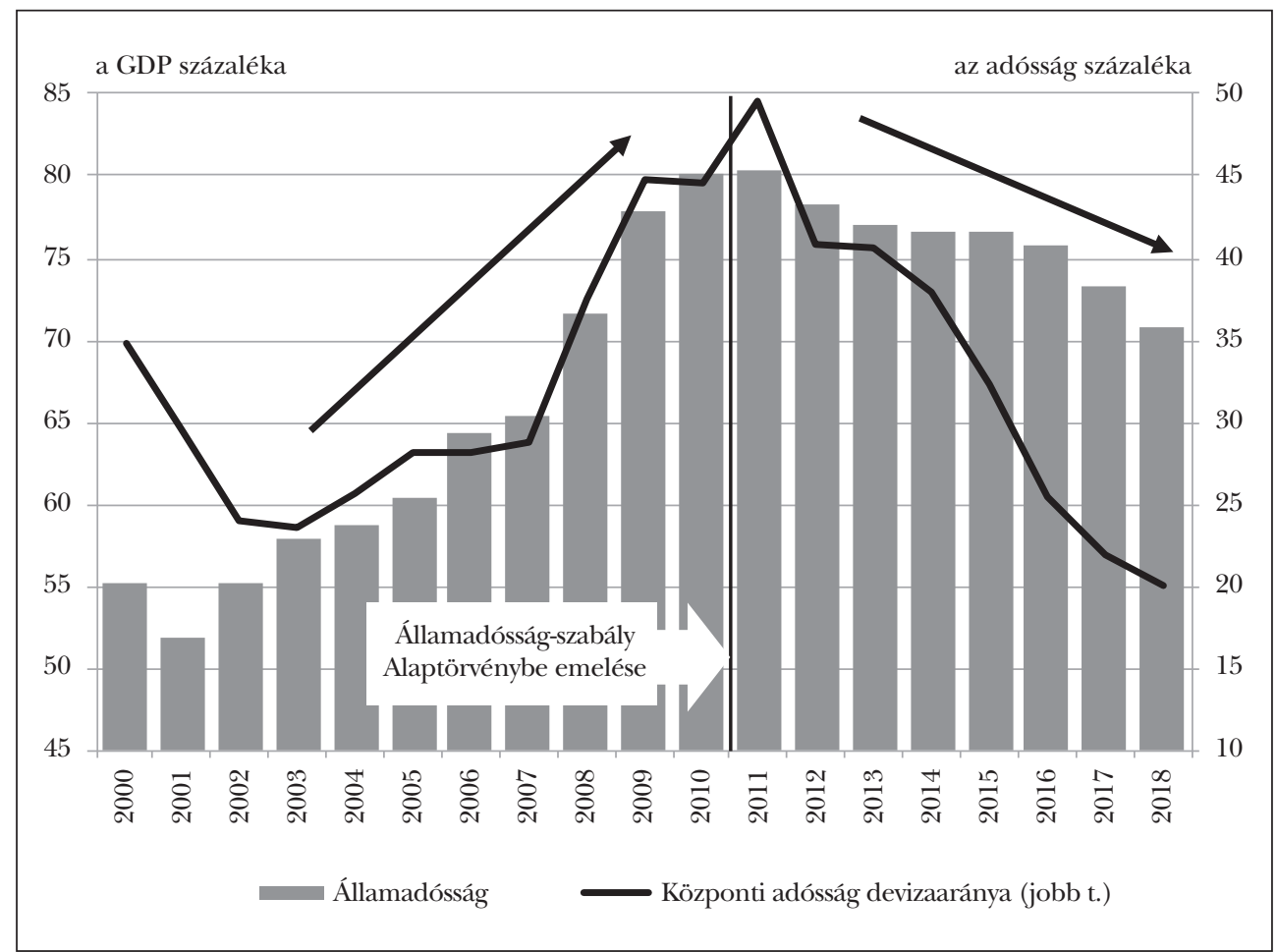

Forrás: $M N B$

zatos emelése csökkentette az inaktivitásba vonulók számát. A foglalkoztatástól való távolmaradáshoz kapcsolódó transzferek összegének és időtartamának lecsökkentése - amely a segélyezési rendszer szigorításaként fogható fel - megakadályozta a munkaerôpiac korai elhagyását. A rugalmas munkavégzési formák - fôként részmunkaidôs foglalkoztatás - alkalmazásának megkönnyítése támogatta bizonyos hátrányos helyzetú csoportok munkaerópiacra lépését.

Az aktivitás növelését célzó kormányzati intézkedésekkel párhuzamosan a növekvô aktivitású - leginkább hátrányos helyzetú - társadalmi csoportok munkaerôpiaci integrációját is célzottan segítette a kormányzat. A leginkább munkaerôkeresletet élénkítô Munkahelyvédelmi Akcióterv (MAT) keretében hátrányos helyzetú munkavállalókat (pl. szakképzetlenek, tartós munkanélküliek, 55 év felettiek) alkalmazó munkáltatók számottevố járulékkedvezményben részesültek. A közfoglalkoztatási programok 2013as kibôvítése segítette az inaktivitásból munkaerôpiacra lépô, az elsôdleges munkaerôpiac felôl gyenge kereslettel rendelkezố csoportok munkához jutását, ezáltal jelentôs részük esetében megfelelő átmenetet biztosított a késôbbiekben az elsôdleges munkaerôpiacra történó belépéshez.

Fơként a munkaerôpiacot érintô, célzott strukturális intézkedések bevezetésének hatására Magyarország aktivitási rátája dinamikusan növekedett 2010 óta. Az aktivitási 


\section{Matolcsy György: A sikeres válságkezelés a 12 gazdasági fordulat tükrében}

rátában való relatív helyzetünk javulása legfôképpen a munkaerôpiaci szempontból hátrányos helyzetú társadalmi csoportokhoz - alacsonyan képzettek, fiatalok, 50 év felettiek és kisgyermekes nôk - köthetô. Az elmúlt közel egy évtizedben jelentôs mértékben növekedett ezen csoportok aktivitási rátája, így az uniós átlagtól vett lemaradás is érdemben mérséklődött ezen csoportok esetében.

A munkaerőpiaci részvétel emelkedését a foglalkoztatottság javulása kísérte, az aktívvá váló munkaerốt a piac felszívta. 2013-ban a foglalkoztatottság meredek emelkedésnek indult, a foglalkoztatottak száma több mint 750 ezer fôvel bôvült 2010-hez viszonyítva.

7. ábra: Az aktívak, a foglalkoztatottak és a munkanélküliek számának alakulása

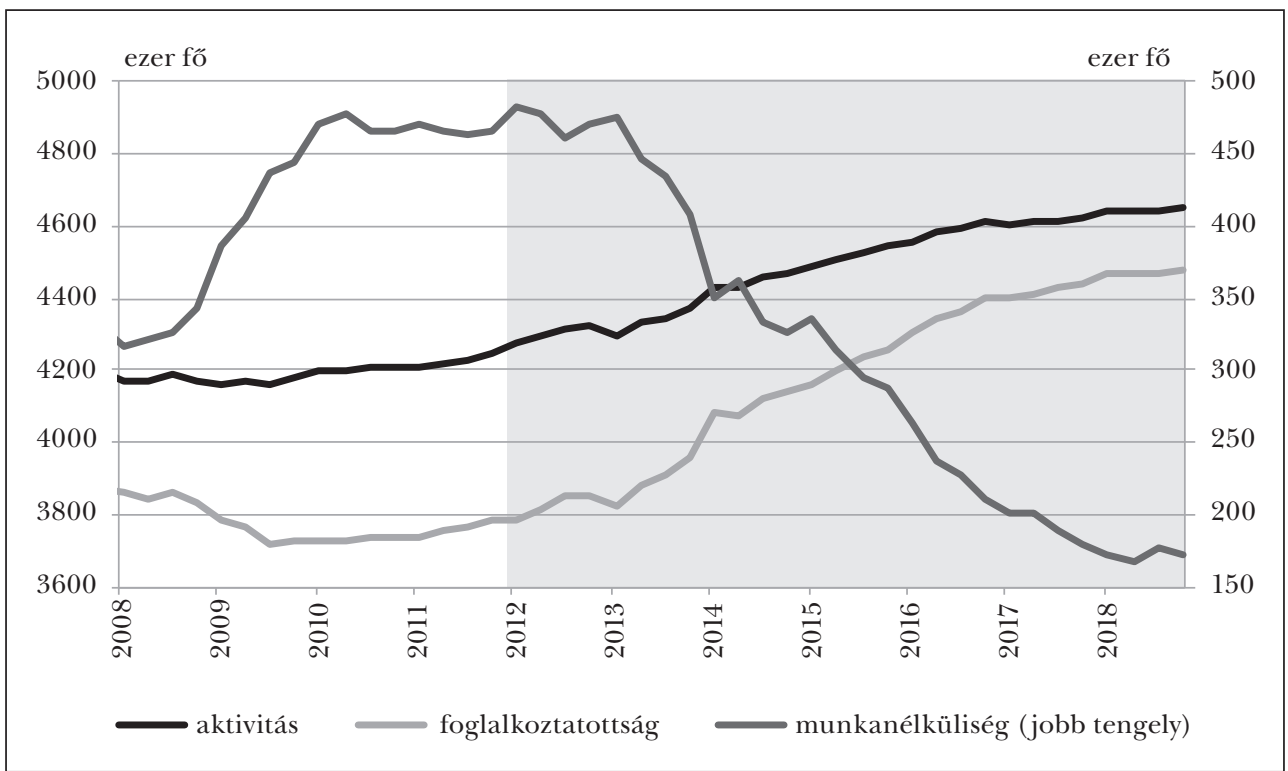

Forrás: KSH

A foglalkoztatottság emelkedésével párhuzamosan a munkanélküliség historikus mélypontra süllyedt. Hazánkban a munkanélküliségi ráta a 2012-es 11 százalékról 3,7 százalékra csökkent 2018-ra, és ezzel jelenleg az egyik legalacsonyabb az Európai Unióban.

A monetáris politika fordulatai - az árstabilitás elérése és fenntartása

A 2008-2009-es válságot követô sikeres válságkezelés alapjait a helyes válaszlépések megtalálása mellett a gazdaságpolitika meghatározó ágai közötti összhang jelentette. Miközben a világ nagy jegybankjai a válság kitörését követôen szinte azonnal korábban nem látott méretú monetáris impulzussal segítették gazdaságaikat, a magyar válságkezelés egészen 2012 nyaráig monetáris szembeszélben zajlott. A monetáris politika 
2013-tól az új jegybanki vezetés kinevezésével vett teljes fordulatot. A jegybanki politika megújulását az intézményrendszer hatékony átalakítása, azaz a Pénzügyi Felügyelet 2013 végi jegybanki integrációja is nagyban meghatározta.

\section{A jegybanki alapkamat csökkentése és hatása}

A kedvezótlen makrogazdasági folyamatokra a világ nagy jegybankjai azonnali monetáris lazítással reagáltak. Az MNB 2012 augusztusában kezdte meg kamatcsökkentési ciklusát, amelynek eredményeként 4 év alatt a kezdeti 7 százalékról három szakaszban 610 bázisponttal csökkentette az irányadó rátát historikus mélypontjára, 0,9 százalékra. A kamatcsökkentési ciklus elindítását több tényezô is támogatta. A magyar kockázati felárak a sikeres költségvetési fordulatnak is köszönhetôen a befektetôi hangulat tartós javulását mutatták, emellett a vezetô jegybankok újabb és újabb lazító lépései is lehetôvé tették a monetáris kondíciók lazítását. A 2010-tôl kezdődő fiskális fordulat, az erôsödő fiskális fegyelem, az államadósság csökkenô pályára állása, a külsô sérülékenység mérséklődése és a hosszú távú növekedés ösztönzését célzó strukturális reformok is támogatták a jegybank lazító lépéseinek megvalósulását (MNB, 2017).

\section{8. ábra: A magyar alapkamat alakulása}

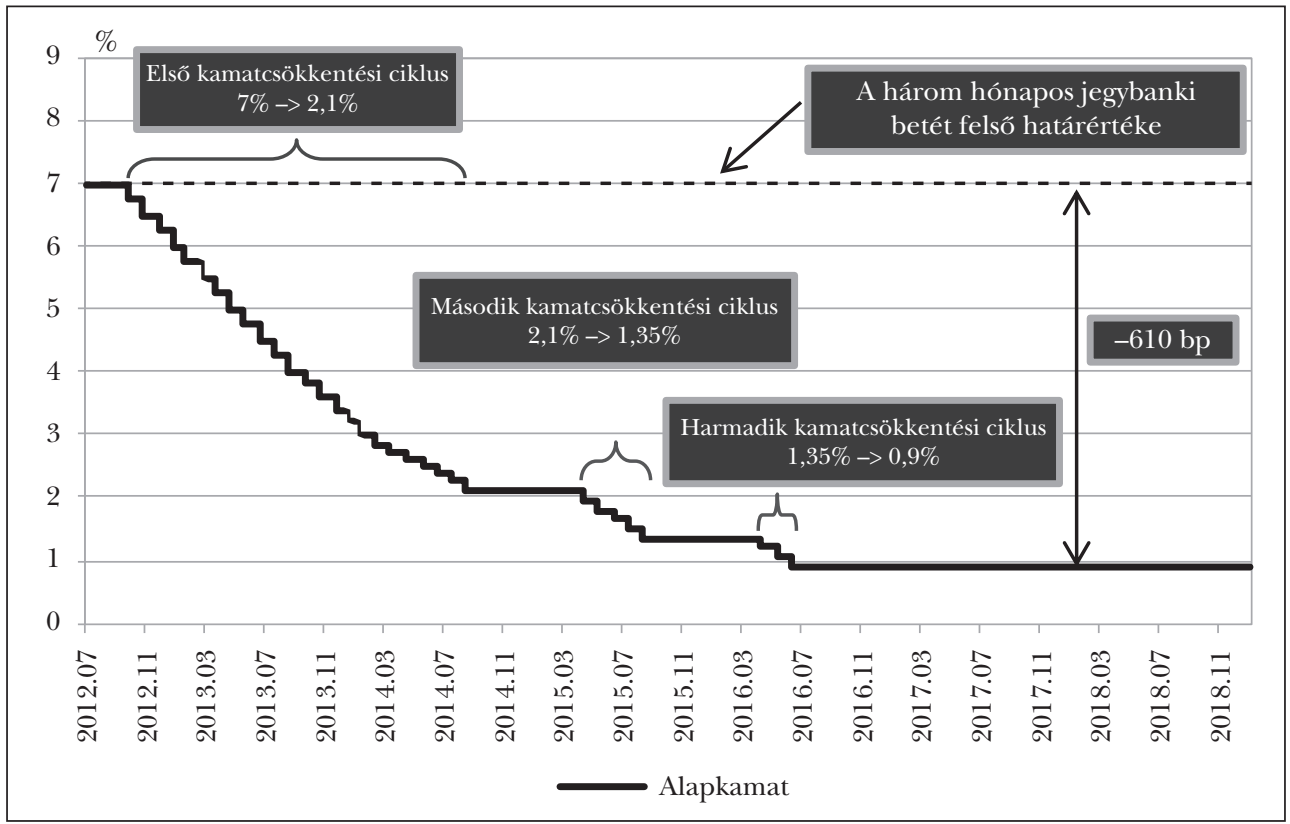

Forrás: $M N B$

Az irányadó ráta csökkentése 2015 végéig, a historikusan alacsony 0,9 százalékpont eléréséig tartott. Azóta az alapkamat ezen a szinten alakul. Az alacsony alapkamat tartós tartása mögött az az elgondolás húzódott meg, hogy a jegybank a monetáris 


\section{Matolcsy György: A sikeres válságkezelés a 12 gazdasági fordulat tükrében}

kondíciók lazítása során egy olyan kamatszint kialakítására törekedett, amely hosszabb távon is összhangban áll az inflációs cél fenntartható módon történô elérésével.

A jegybank kamatcsökkentési ciklusainak jelentôs növekedési hatásai voltak. Az alapkamat érdemi csökkentése mérsékelte a deflációs környezet kialakulásának esélyét, és jelentôsen hozzájárult a kibocsátás szintjének emelkedéséhez. A kamatcsökkentési ciklus kedvezó makrogazdasági hatásai mellett sikerült megórizni a gazdaság egyensúlyát, a gazdaság külsô finanszírozási képessége is tartósan stabilan alakult.

A monetáris kondíciók lazítása a pénzügyi piacokon is kifejtette hatását. A kamatkondíciók lazulása nagymértékben csökkentette a magánszektorra nehezedő kamatterheket, ezáltal sikerült megakadályozni a hitelállomány, a fogyasztás és a beruházás további esését a válságot követôen. A monetáris lazítás nemcsak a magánszektorra volt kedvezô hatással, hanem a rövid és hosszú lejáratú állampapírok hozamai is jelentôsen mérséklődtek. Az állampapírpiaci hozamok mérséklôdésével az államháztartás pozíciója is javult a csökkenố kamatkiadások következtében. Míg 2013-ban az államháztartás kamatkiadásai meghaladták a GDP 4 százalékát, addig a forintadósság fokozatos átárazódása következtében 2018-ra ez a mérték majdnem megfeleződött.

\section{A jegybanki eszköztár átalakítása, a nemkonvencionális eszközök bevezetése}

A Magyar Nemzeti Bank 2016 nyarán-ôszén új monetáris politikai keretrendszert vezetett be, amivel az alapkamat tartós tartása és az inflációs folyamatok figyelembevétele mellett célzott, nemkonvencionális monetáris lazítást hajtott végre. A rendszer központi eleme az irányadó eszköz átalakítása, a három hónapos betét mennyiségi korlátozása volt, amelyen keresztül az MNB támogatta a hitelezést, az önfinanszírozást, valamint biztosította a releváns pénzpiaci hozamok kamatfolyosón belüli további csökkenését. A 2016 utolsó negyedévében elkezdett mennyiségi korlátozást az $\mathrm{MNB}$ az $\mathrm{O} / \mathrm{N}$ hitelkamat alapkamatra csökkentésével, azaz a teljesen aszimmetrikus kamatfolyosó kialakításával, valamint a tartalékráta 2 százalékról 1 százalékra való mérséklésével támogatta. 2016 ôszén az MNB bevezette a forintlikviditást nyújtó finomhangoló devizacsere (FX-swap) eszközt, amelyek segítségével a jegybank heti rendszerességú tendereken biztosítja a megfelelô mértékú bankrendszeri likviditás fennmaradását.

A mennyiségi korlát bevezetésével az MNB három hónapos betéti állománya a 2016. szeptember végi csaknem 2000 milliárd forintról 2016. novemberre 900 milliárd forint közelébe, majd 2017 végére 75 milliárd forintra csökkent, 2018 decemberében pedig az eszköz kivezetésre került. A bankrendszer többletlikviditása $\mathrm{O} / \mathrm{N}$ betétben jelent meg, a kiszorult likviditás hozamleszorító hatása pedig minden releváns piacon érezhetô volt. A mennyiségi korlátozás 2016 nyári bevezetése után a hozamok a kamatfolyosó aljára csökkentek. A mennyiségi korlátozás rendszerének hatékony múködését segítette, hogy 2016 májusában az MNB kezdeményezésére megújult a BUBOR (budapesti bankközi forint hitelkamatláb) jegyzési rendszere, a kötelezó árjegyzési rendszer bevezetésével emelkedett a fedezetlen bankközi piac forgalma, és ezzel párhuzamosan nôtt a BUBOR-kamatok információtartalma (MNB, 2017). 


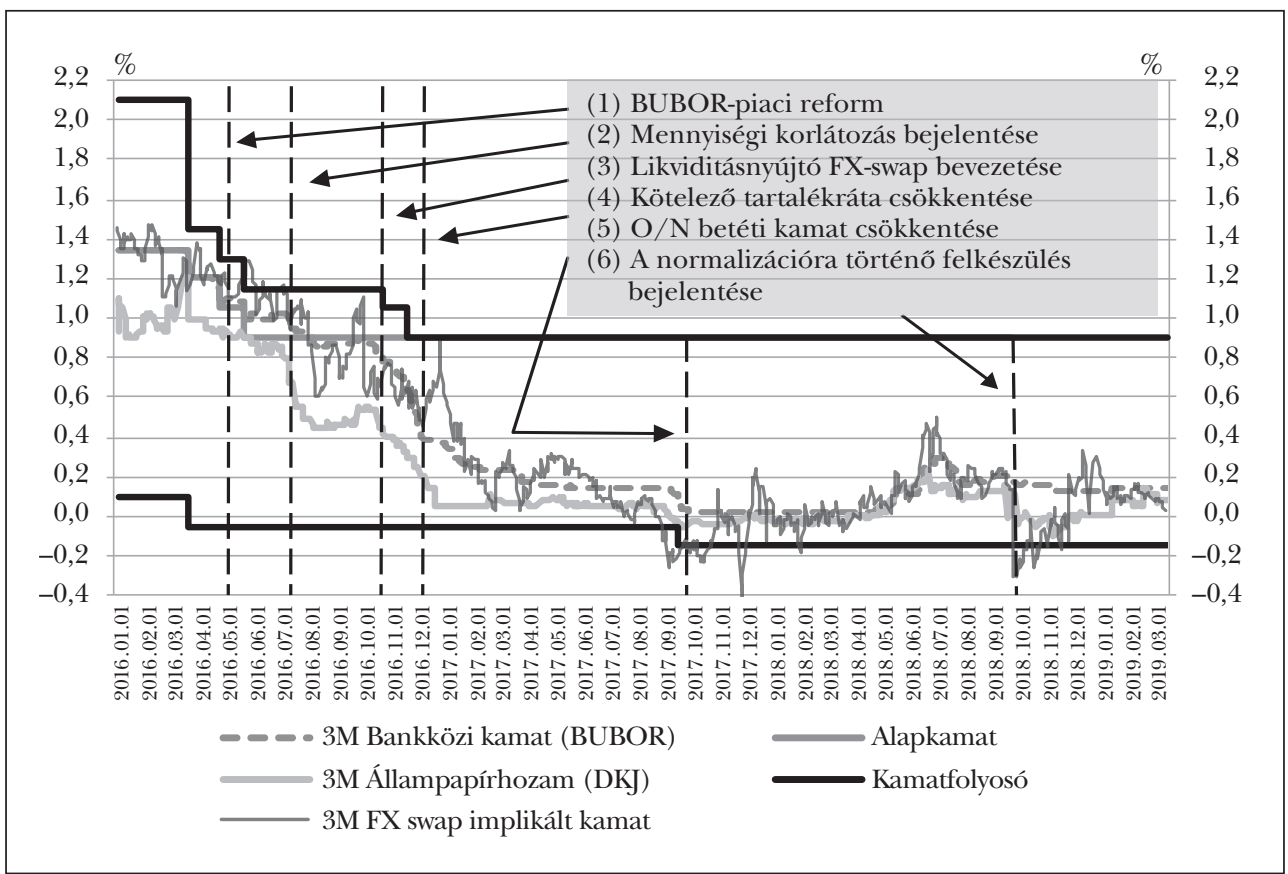

Forrás: $M N B$

A Monetáris Tanács 2017. novemberi ülésén azt a döntést hozta, hogy a laza monetáris kondíciók a hozamgörbének nemcsak a rövid, hanem hosszabb szakaszán is érvényesüljenek. Ennek biztosítása érdekében a Monetáris Tanács két nemkonvencionális eszköz 2018. januári bevezetéséról döntött, amelyek a monetáris politikai eszköztár szerves részét képezték. A monetáris politikai kamatcsereügyletek (MIRS) általános monetáris politikai eszközként, a jelzáloglevél-vásárlási program (JVP) pedig célzott programként került bevezetésre, amely deklaráltan a kamatfixált jelzáloghitelek terjedésének és jelzáloglevél-piac fejlódésének elôsegítését szolgálta.

Mind a MIRS, mind pedig a jelzáloglevél-vásárlási program elérte a kitúzött célokat. Az eszközök támogatták a laza monetáris kondíciók hosszú futamidôkre való kiterjesztését, illetve a piac stabilitását, hozzájárultak a jelzáloglevél-piac fejlesztéséhez, valamint a bankok kamatkockázatának csökkentéséhez és így a hosszú lejáratú, fix kamatozású jelzáloghitelek további elterjedéséhez, ami 2018 végére az év eleji 61 százalékos új kibocsátási arányról 90 százalék közelébe emelkedett. A jelzáloglevél-hozamok állampapírhozamokhoz mért felára a kivezetés bejelentéséig a hozamgörbe teljes szakaszán negatív tartományba süllyedt, az alacsony finanszírozási költségek pedig érdemben támogatták az új kibocsátásokat. A fix kamatozású jelzáloglevelek bruttó kibocsátása a piaci volumen elôzố hét évének összegével egyezett meg, ami azt jelenti, hogy a program érdemi mértékben támogatta a jelzáloglevélpiac fejlődését. 
Matolcsy György: A sikeres válságkezelés a 12 gazdasági fordulat tükrében

10. ábra: Fix kamatozású jelzáloglevelek éves piaci bruttó kibocsátása

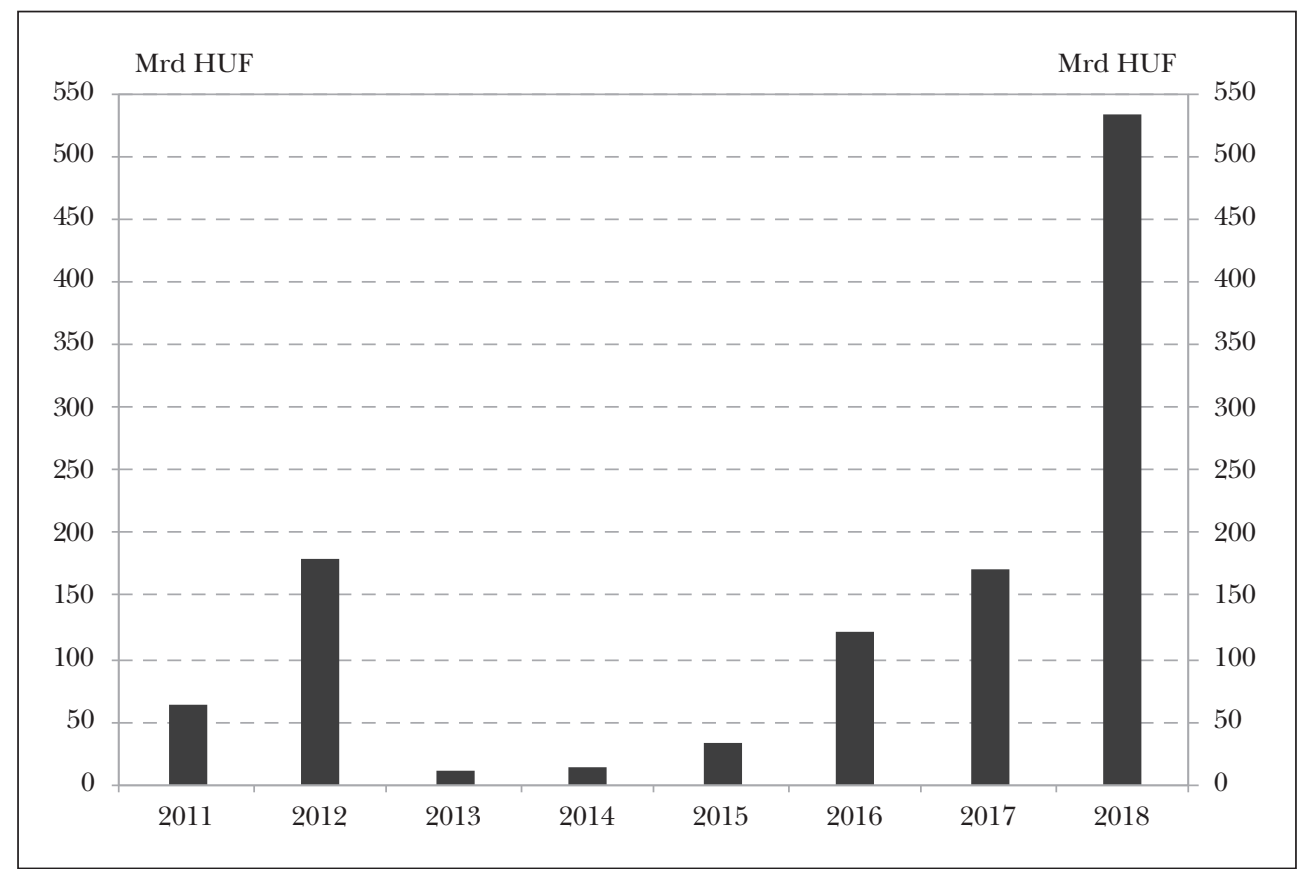

Forrás: $M N B$

A jelzáloglevél-piac élénkülését és a bankok hosszú lejáratú forint forrásbevonását az MNB, a jelzáloglevél-vásárlási program kivezetését követôen, a monetáris politikai eszköztáron kívüli eszközeivel, kiemelten a jelzáloghitel-finanszírozás megfelelési mutatóra ${ }^{1}(\mathrm{JMM})$ vonatkozó szabályozással továbbra is támogatja.

Az Önfinanszírozási program - lépések egy stabilabb gazdaságért

2014 áprilisában sor került az Önfinanszírozási program meghirdetésére, amelynek végrehajtása során az MNB átalakította monetáris politikai eszköztárát annak érdekében, hogy a bankok többletlikviditásukat ne jegybanki betétekben, hanem hosszabb lejáratú, likvid értékpapírokban tartsák. Ez a magyar értékpapírpiac sajátosságai miatt elsôsorban az állampapírok iránti banki kereslet megemelkedését jelentette. A jegybank programja, az Államadósság-kezelő Központ forintkibocsátásból finanszírozott devizatörlesztései, valamint a bankok együttmúködô hozzáállása és alkalmazkodása együttesen tette lehetôvé az egészségesebb adósságszerkezet felé történô elmozdulást, illetve a külsô kitettség fokozatos mérséklődését (MNB, 2017).

Az Önfinanszírozási program jelentôsen csökkentette az ország külsô sérülékenységét, erôsítette a pénzügyi stabilitást, javította Magyarország nemzetközi megítélését. 2014 és a program aktív szakaszának végét jelentô 2016-os év között Magyarország úgy tudott közel 11 milliárd euró értékú devizaadósságot forintforrásból visszafizetni, 
11. ábra: A magyar államadósság tulajdonosi szerkezete

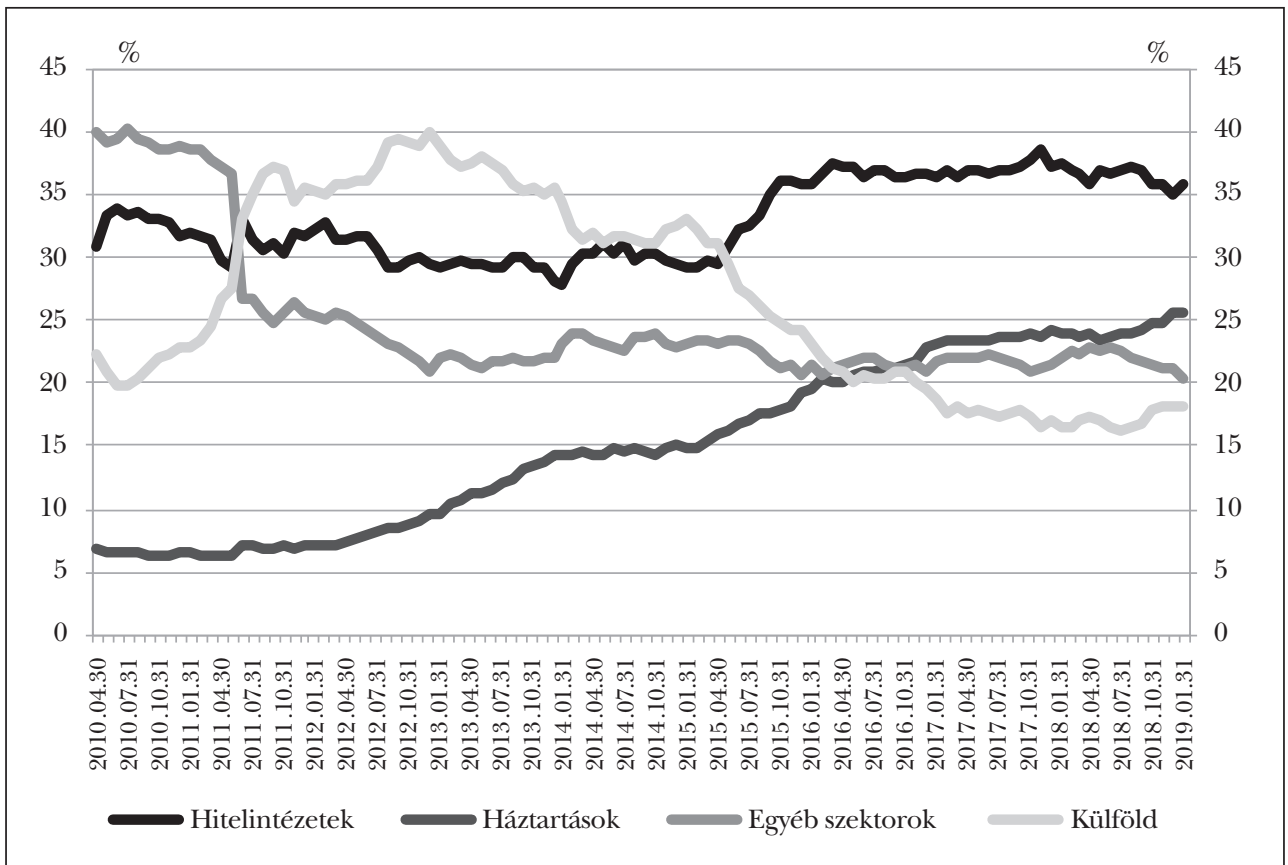

Megjegyzés: 2012 decemberéig a hitelintézeti arány a pénzpiaci alapok állományait is tartalmazza.

Forrás: $M N B$

hogy közben - az inflációs célkitúzéssel összhangban - csökkentek az állampapírpiaci hozamok. Az államadósság devizaaránya a 2014-es 42 százalékról 2016 végére 25 százalékra, majd 2018 végére 20 százalék alá apadt. Az Önfinanszírozási program kiemelkedôen fontos szerepet játszott a hazai befektetôkre és forintra támaszkodó finanszírozás megvalósításában, eredményei pedig megalapozták a teljesen magyar kézben tartott államadósságra vonatkozó stratégiai cél kitúzését.

A jegybanki mérleg fordulata - amikor a kevesebb több

A külsố sérülékenység csökkenése révén lehetôvé vált a jegybanki mérleg fordulata, ami kedvezô hatással bírt az MNB-re és a nemzetgazdaságra egyaránt. Magyarország a válság kitörésekor az állam kedvezôtlen finanszírozási helyzete miatt hitelfelvételre kényszerült a nemzetközi intézményektôl, ami a jegybankmérleg eszköz- és forrásoldalának emelkedésével járt. A felduzzadó mérleg a bankrendszeri likviditás növekedése miatt jelentôs kamatköltséget jelentett az MNB számára. A gazdaság válság utáni alkalmazkodásával kialakult jelentôs finanszírozási képesség, az ennek nyomán csökkenô külsô adósság, illetve külsố sérülékenység lehetôvé tették, hogy a jegybankmérleget célzott programokkal a tartalékmegfelelés veszélyeztetése nélkül csökkenteni lehessen. Ez nemzetközi összevetésben is említésre méltó fejlemény. A válság után a világ nagy részében ugyanis az a trend 


\section{Matolcsy György: A sikeres válságkezelés a 12 gazdasági fordulat tükrében}

rajzolódott ki, hogy a jegybankok monetáris politikai céljaik érdekében általánosságban emelték mérlegfóösszegüket. A válságot követô monetáris politikai lazító ciklusában (2008-2014) a Fed GDP-arányos mérlegfőösszege 17 százalékponttal, az EKB mérlege a 2014 után megkezdett eszközvásárlásai következtében 20 százalékponttal, a cseh jegybanké pedig 2013 óta - a devizatartalék felduzzadása miatt - 40 százalékponttal emelkedett. Ezzel szemben 2013, a magyar monetáris politikai fordulat kezdete óta az MNB GDP-arányos mérlegfôösszege 12 százalékponttal csökkent. Ráadásul hazánk esetében a jegybanki mérleg csökkentésével párhuzamosan annak szerkezete is hatékonyabbá vált, hiszen érdemben csökkent a kamatozó források aránya. A jegybanki mérleg fordulata révén az alacsony hozamkörnyezet ellenére a monetáris politikának maradt mozgástere, és a monetáris transzmisszió hatékonysága is javult. Fontos hangsúlyozni, hogy az MNB - a nemzetközi folyamatokkal ellentétben - az elindított programokkal a mérleg szúkülése mellett tudta fenntartani a laza monetáris kondíciókat (Erhart et al., 2015).

\section{2. ábra: Az MNB-mérleg fóbb elemeinek GDP-arányos alakulása (éves átlagos értékek)}

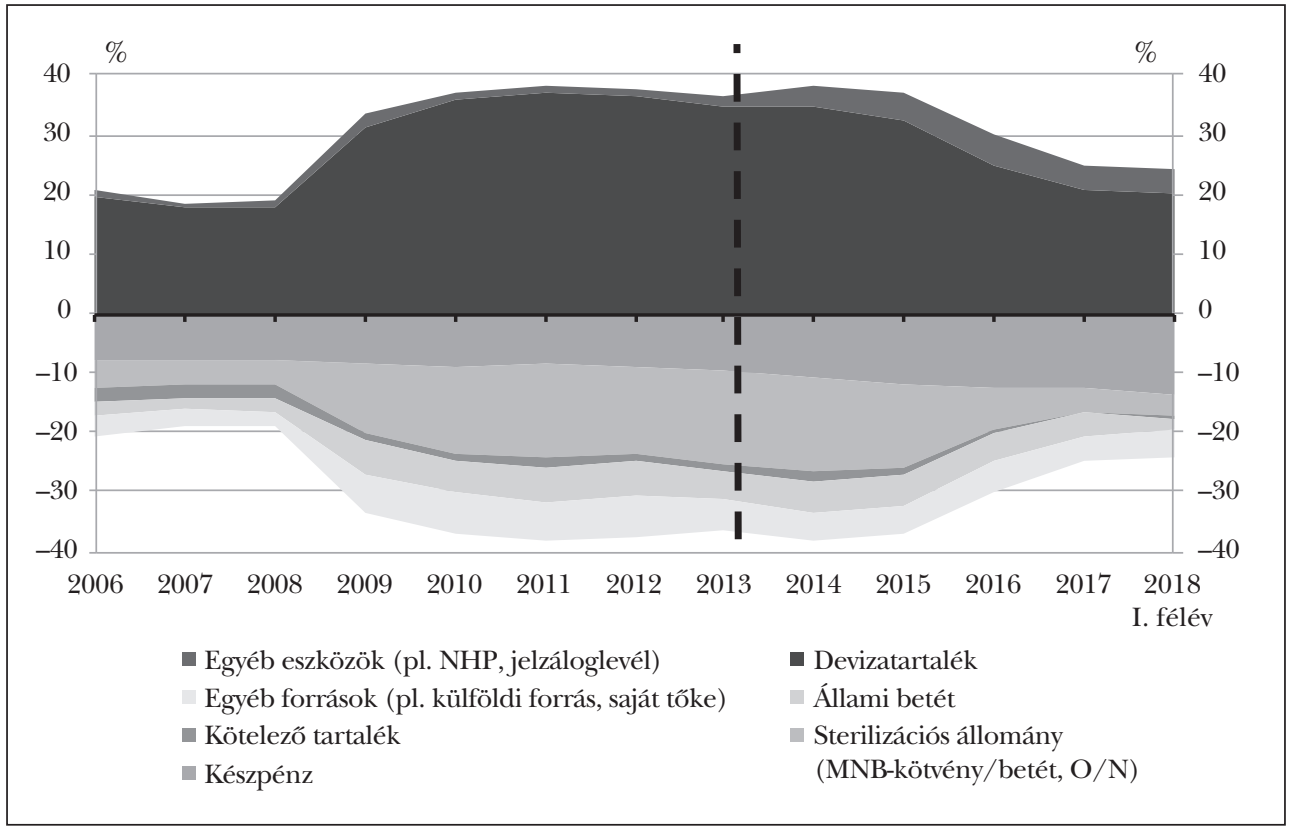

Forrás: $M N B$

Hitelezési fordulat - megtörik a jég a befagyott hitelpiacon

\section{Vállalati hitelezés}

A 2007-2008-as pénzügyi válság kitörését követôen a hazai bankrendszer hitelkínálata drasztikusan visszaesett, 2009 és 2013 második negyedéve között a hitelösszeomlás jelensége (credit crunch) jellemezte a vállalati hitelezést (Balog et al., 2014). A vállalati 
hitelállomány a folyósítások és törlesztések hatására évente átlagosan mintegy 4-5 százalékkal mérséklődött ezekben az években. A hitelállomány összehúzódása különösen érzékenyen érintette az egyéb forrásokhoz csak rendkívül korlátozottan hozzáférố mikro-, kis- és közepes méretú vállalatokat: e vállalatok hitelei évente mintegy 4 és 8 százalék közötti ütemben mérséklődtek.

13. ábra: A teljes vállalati és a kkv-szektor hitelállományának növekedési üteme

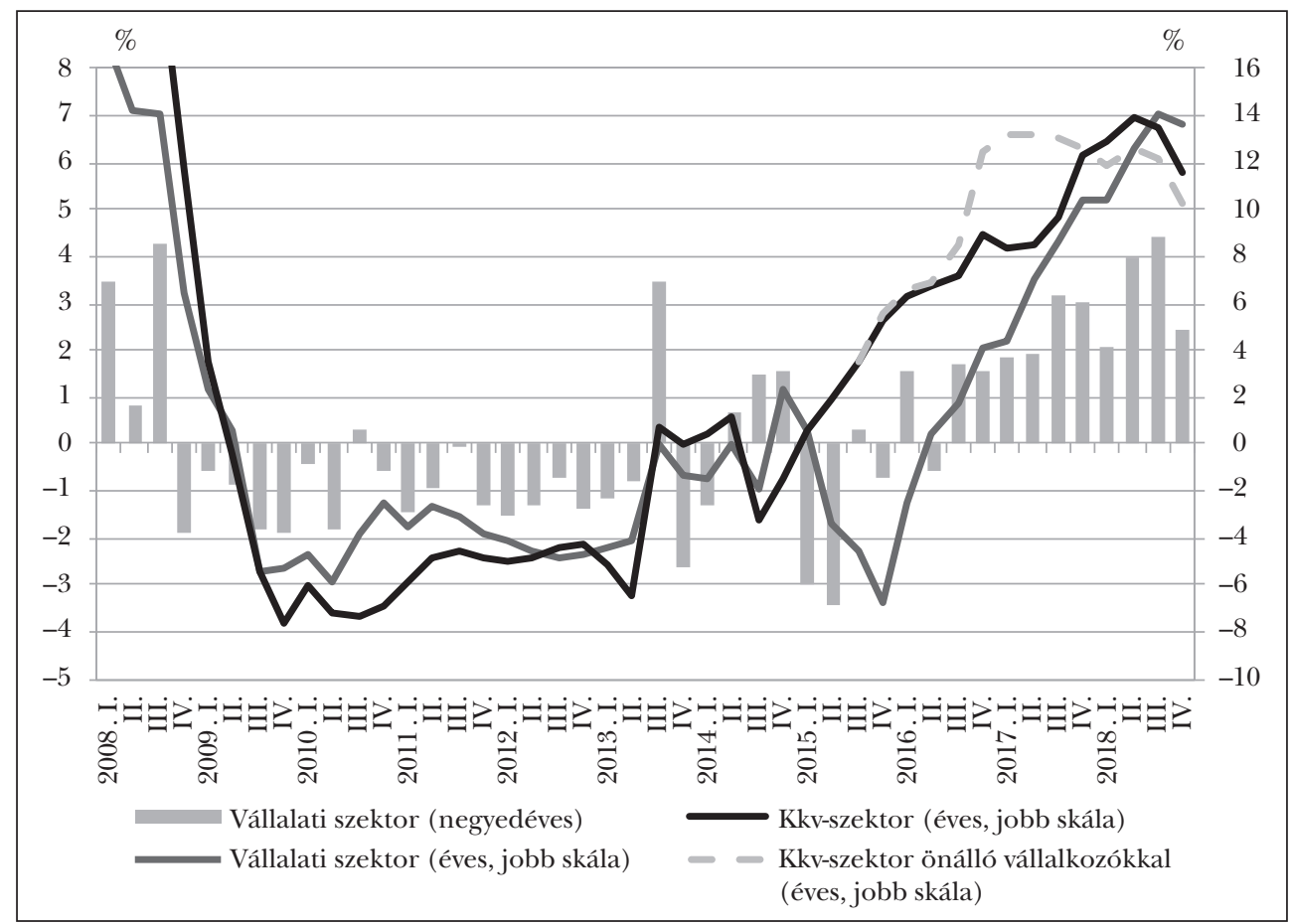

Megjegyzés: Tranzakció-alapú, a kkv-szektor 2015. negyedik negyedév elótt bankrendszeri adatok alapján becsülve.

Forrás: $M N B$

A kkv-hitelezésben a 2013-ban elindított Növekedési Hitelprogram törte meg a negatív spirált, és stabil növekedési pályára állította a folyamatokat. A teljes vállalati szektor hitelállománya kis késéssel szintén követte ezt a trendet, így 2018 végére már mind a teljes vállalati hitelállomány, mind a kkv-szektor hitelei 10 százalék feletti ütemben növekedtek (MNB, 2019b).

\section{A Növekedési Hitelprogram bevezetése}

A bankok visszafogott hitelezési hajlandósága, valamint a kockázati felárak emelkedése a hazai tulajdonú, banki finanszírozásban szúkölködô kis- és középvállalati (kkv) szektor szereplőit sújtotta leginkább, megnövelve ezzel a hitelezési piac lefagyásának kockázatát. 


\section{Matolcsy György: A sikeres válságkezelés a 12 gazdasági fordulat tükrében}

Az MNB a monetáris politikai eszköztár új, célzott elemeként 2013 júniusában elindította a Növekedési Hitelprogramot (NHP) a kkv-k hitelezésében tapasztalt tartós piaci zavar enyhítése, a gazdaság élénkítése, valamint a pénzügyi stabilitás megerôsítése érdekében. A jegybank az NHP keretében 0 százalékos kamatozású refinanszírozási hitelt nyújtott a hitelintézeteknek, amit azok legfeljebb 2,5 százalékos kamatmarzs mellett hitelezhettek tovább a kkv-k számára, akár 10 éves időtávra. Ez igen kedvezó és kiszámítható finanszírozási lehetôséget jelentett, ráadásul árfolyamkockázat nélkül.

Az NHP 2013 júniusában indult, mindössze három hónapig tartó elsố szakaszában teljesültek a kitúzött rövid távú célok: a hitelpiaci korlátok mérséklôdtek, és a bankok közötti verseny is fokozódott. A második szakaszban a növekedési hatás fokozása érdekében a hangsúly már az új hiteleken, azon belül is a beruházási hiteleken volt, hitelkiváltásra csak korlátozott mértékben volt lehetôség. Az MNB 2015 ôszén az NHP fokozatos kivezetésérôl határozott, a program elindításakor kitúzött célok addigra ugyanis sikeresen teljesültek. A harmadik szakasz - a kivezetési szándékkal összhangban - a korábbiaknál még célzottabb volt. Egyfelől kizárólag beruházási célú forintfinanszírozásra adott lehetôséget, másfelól lehetôvé tette a természetes devizafedezettel rendelkezô kkv-k számára a devizafinanszírozást.

14. ábra: A hitelcélok megoszlása az NHP egyes szakaszaiban

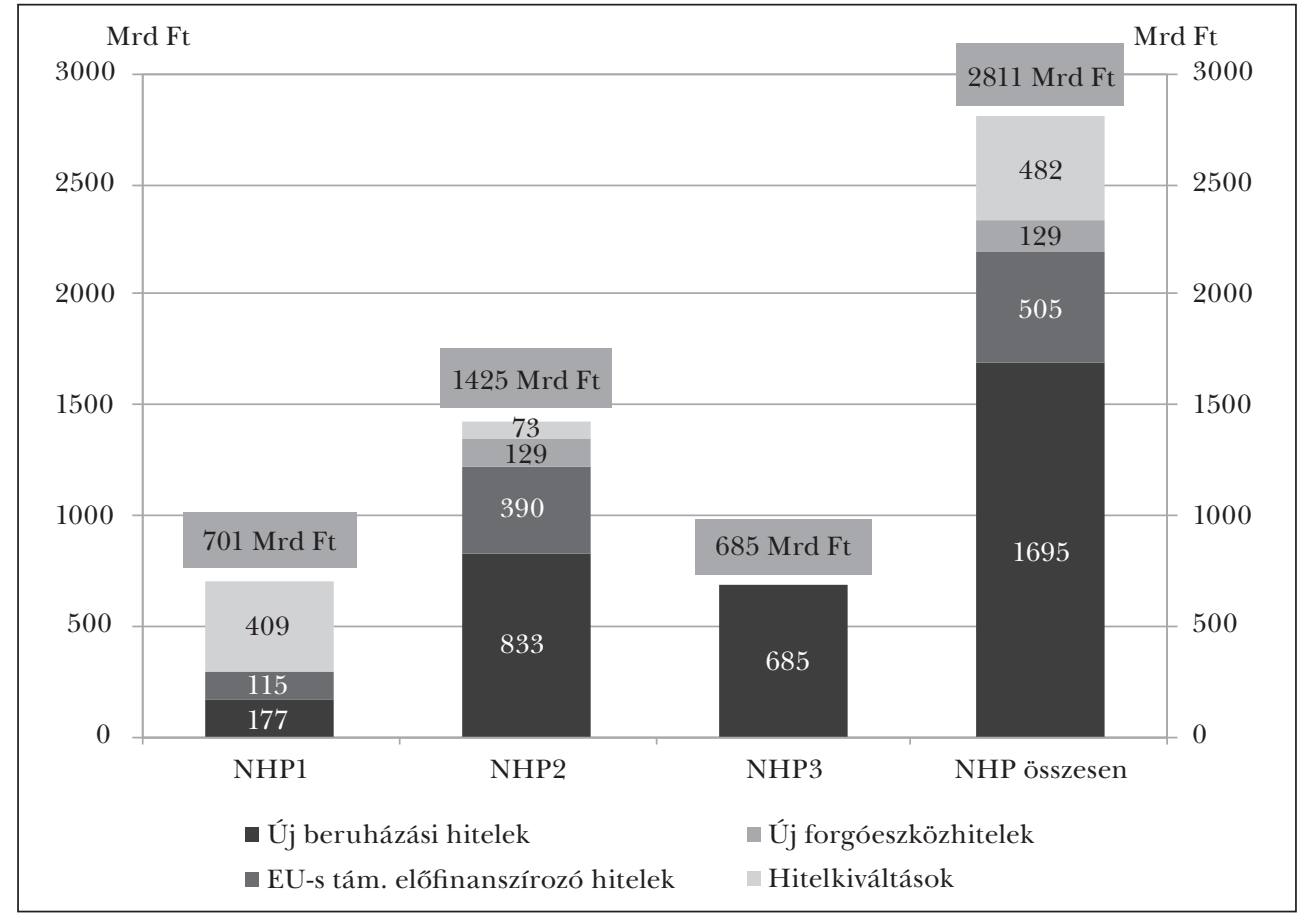

Megjegyzés: az NHP második szakaszára vonatkozó adat tartalmazza az - azzal párhuzamosan futó $N H P+$ konstrukcióban létrejött 23 Mrd forintnyi hitelt is.

Forrás: $M N B$ 
Az NHP 2017 márciusáig tartó múködésének közel négy éve alatt a program három szakaszában együttvéve közel 40000 hazai vállalkozás jutott finanszírozáshoz mintegy 2800 milliárd forint értékben. Ebból közel 1700 milliárd forint szolgálta beruházások finanszírozását. A program a kkv-k hitelhez jutási feltételeinek javításán túl jelentôs indirekt hatást is gyakorolt azáltal, hogy egy korábban nem megfelelően múködő hitelpiacot állított helyre, ami további tartós hozzájárulást jelentett a gazdaság bóvüléséhez (MNB, 2018a).

\section{5. ábra: A kkv-szektor hitelállományának növekedési üteme}

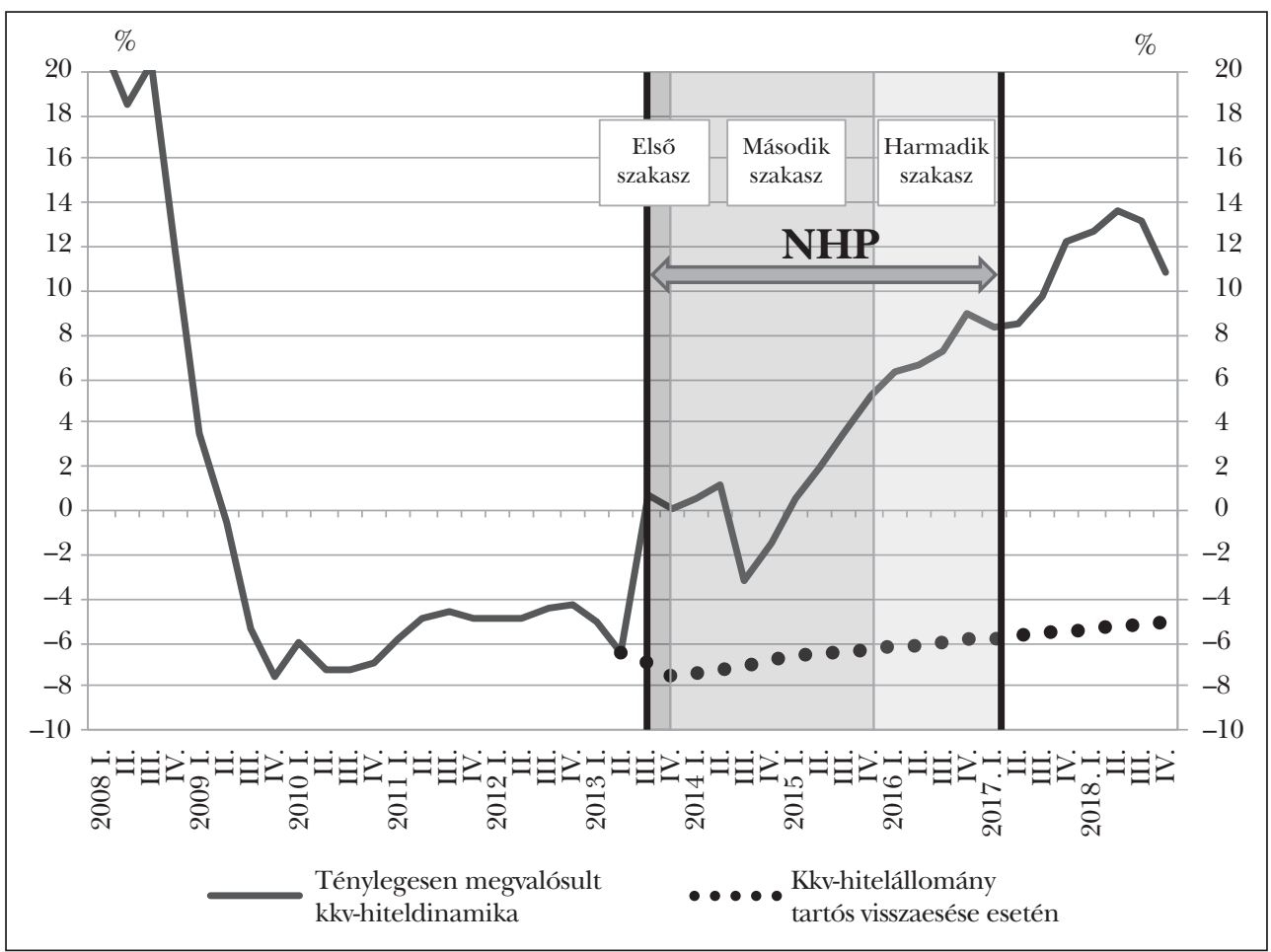

Forrás: $M N B$

\section{A Piaci Hitelprogram bevezetése}

Az NHP fokozatos kivezetése jegyében, annak harmadik szakaszával párhuzamosan indult el 2016 elején a Piaci Hitelprogram (PHP), amelynek célja a jegybanki refinanszírozás nélküli, piaci alapú hitelezés térnyerésének elôsegítése volt.

A hitelezési aktivitás támogatására a PHP-n belül két jegybanki eszköz együttes használata, a hitelezési feltételhez kötött kamatcsere-eszköz (HIRS), illetve a preferenciális betételhelyezési lehetôség szolgált. A HIRS lehetôséget nyújtott a bankoknak a hosszú lejáratú kkv-hiteleik kamatkockázatának fedezésére, miközben az eszköz igénybevételével a hitelintézetek vállalták, hogy az ügyletek fennállása alatt, azaz 3 éven 
keresztül az ügyletek értékének legalább negyedével növelik nettó kkv-hitelezésüket. A preferenciális betételhelyezés keretében a HIRS-ügyletet kötô bankok számára a jegybank lehetôséget biztosított arra, hogy likviditásuk nagyobb részére alapkamatot kaphassanak (MNB, 2015).

A PHP elsố szakaszában, 2016-ban a kkv-k által vállalt hitelnövekmény közel 200 milliárd forint volt, amely nemzetgazdasági szinten 5 százalékos kkv-hitelállomány-növekedésnek felelt meg. A PHP második szakasza 2017 júliusában indult, amelynek keretében a bankok 2017. évi kkv-hitelezési vállalása tovább emelkedett (MNB, 2019b).

16. ábra: A Piaci Hitelprogram keretében tett hitelezési vállalások teljesitése

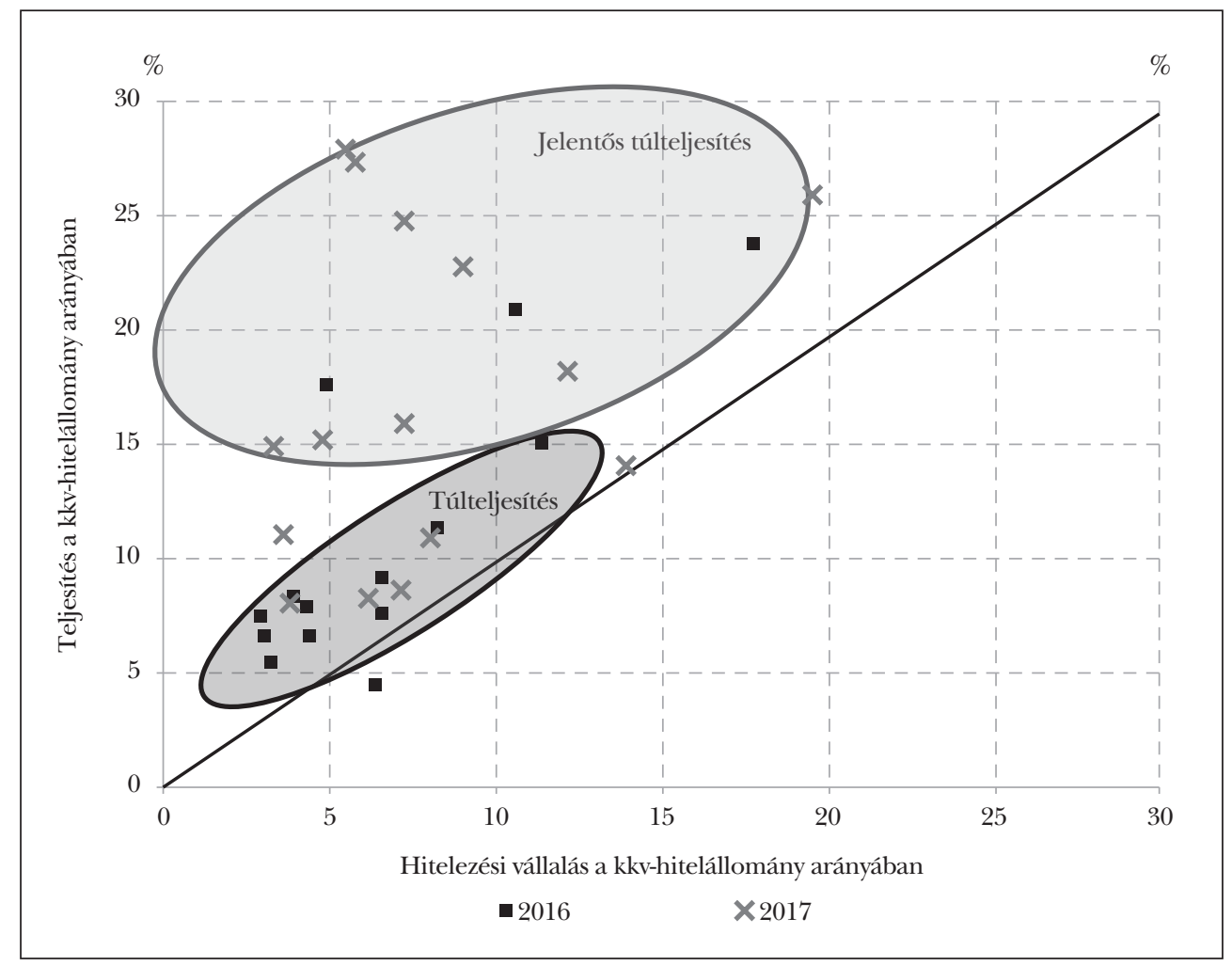

Forrás: $M N B$

Az NHP fix program bevezetése

Jóllehet 2018-ra a vállalati hitelezés dinamikája megfeleló szintre került, szerkezete továbbra sem volt kellóen egészséges. A kkv-hitelek futamidejének eloszlása a rövidebb lejáratok irányába tolódott el, és ismét visszaesett a rögzített kamatozású hitelek részaránya is.

Az MNB ezért a már korábban is jelentôs eredményeket elérni képes, a hitelezés volumenére és szerkezetére egyaránt kedvezô hatást gyakorló eszköz újbóli alkalmazása mellett döntött, ezért 1000 milliárd forintos keretösszeggel az NHP újabb konst- 
rukcióját indította el 2019 elején. Az NHP fix néven meghirdetett új konstrukció a legfontosabb paramétereiben és a lebonyolítás módjában megegyezik az NHP korábbi szakaszaiban elôírtakkal, azonban annál is célzottabb. Kizárólag beruházási célra vehetô igénybe, legalább 3 éves futamidôre. Újdonságot jelent, hogy a program likviditási szempontból semleges, tekintettel arra, hogy az NHP fix keretében folyósított hitelvolumenból fakadó banki többletlikviditás a preferenciális betételhelyezés révén alapkamaton sterilizálásra kerül (MNB, 2018a).

17. ábra: A legfeljebb 1 millió euró összegú új vállalati forinthitel-szerzôdések megoszlása kamatfixálási periódus alapján

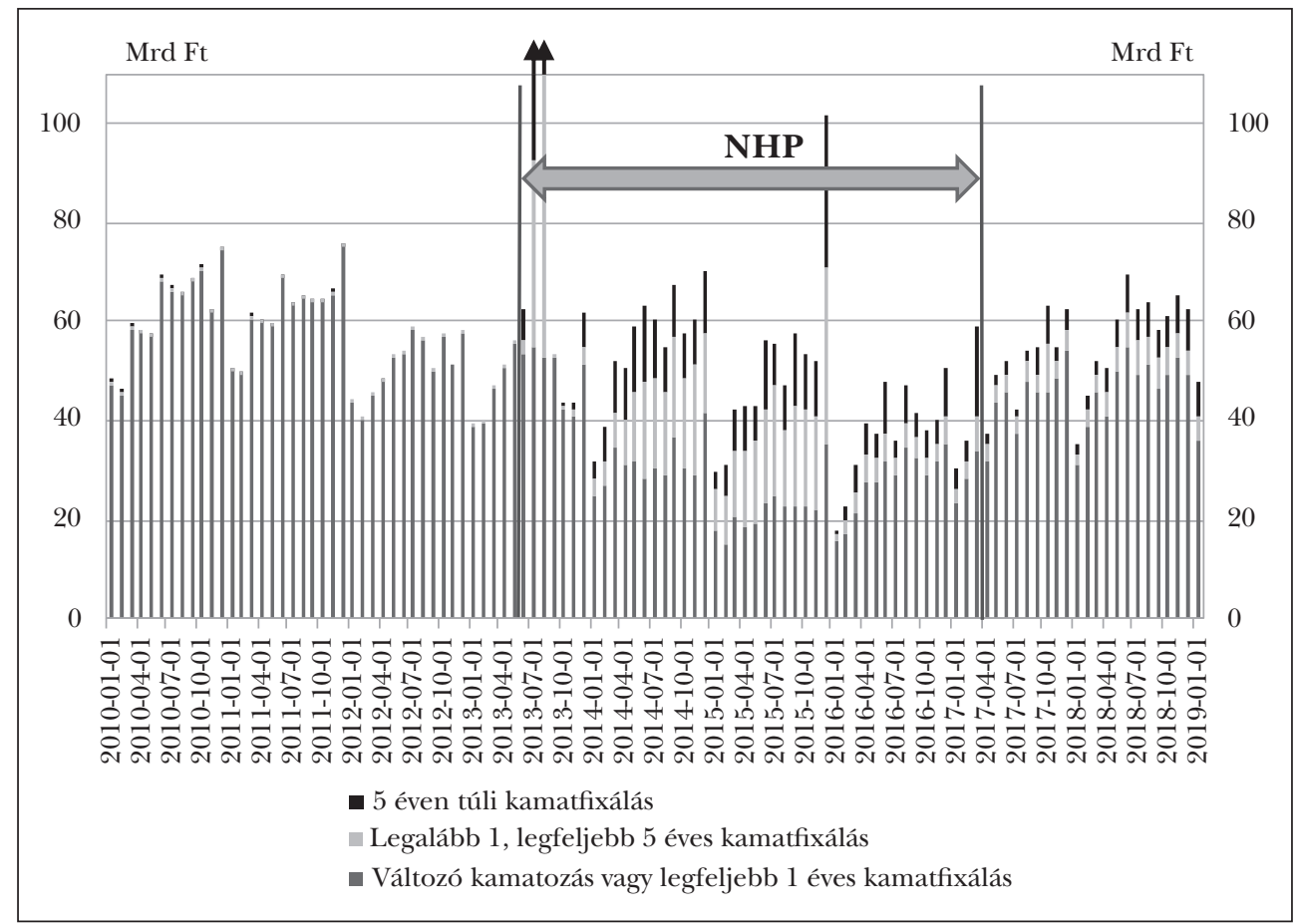

Forrás: $M N B$

\section{Háztartási hitelezés}

A háztartások hitellel kapcsolatos attitúdjét a válság kitörését követően az óvatosság és az adósság leépítésére való törekvés határozta meg. Ennek megfelelôen a hitelintézetek háztartási hitelállománya 2010 és 2016 között folyamatosan csökkent, amiben a kormányzati programok (kedvezményes végtörlesztés, egyoldalú kamatemelések és az árfolyamrés elszámolása) is komoly szerepet játszottak.

Az új szerzôdéskötéseket tekintve a 2012-es és a 2013-as évek jelentették a mélypontot. Ezekben az években a lakossági hitelkibocsátás éves volumene alig haladta meg a 300 milliárd forintot, ami a 2008-as év 2000 milliárd forintot meghaladó szerzôdés- 
Matolcsy György: A sikeres válságkezelés a 12 gazdasági fordulat tükrében

kötéseihez képest drasztikus visszaesésnek könyvelhetô el. 2013-tól kezdve azonban a reálgazdaság és a jövedelmek növekedésével párhuzamosan elindult a lakossági hitelpiac fokozatos élénkülése is. 2018-ban a teljes lakossági hitelkibocsátás már elérte az 1500 milliárd forintot, és a teljes háztartási hitelállomány is 7 százalékot meghaladó mértékben emelkedett. A lakossági hitelezésen belül kiemelten fontos szerepet játszó lakáshitelpiac 2018-ban az új szerződéskötéseket tekintve nominális értelemben már elérte a válság kitörése elôtti szintet. A jelenlegi hitelkibocsátás ráadásul jóval nagyobb lejáró hitelállományok mellett valósul meg, így a szerzódéskötések hasonló volumene jóval alacsonyabb adósságnövekedést jelent a szektor egésze szintjén.

Mindez nyilvánvalóvá válik, ha a háztartási hitelállományt a GDP arányában vizsgáljuk: míg a válság kitörését követôen ez a mutató 31 százalékon állt (meghaladva ezzel több régiós ország értékét), jelenleg a háztartási hitelállomány GDP-arányos nagysága a 15 százalékot sem éri el, ami az egyik legalacsonyabb értéket jelenti az Európai Unióban.

\section{8. ábra: A GDP-arányos háztartási hitelállomány nemzetközi összehasonlításban}

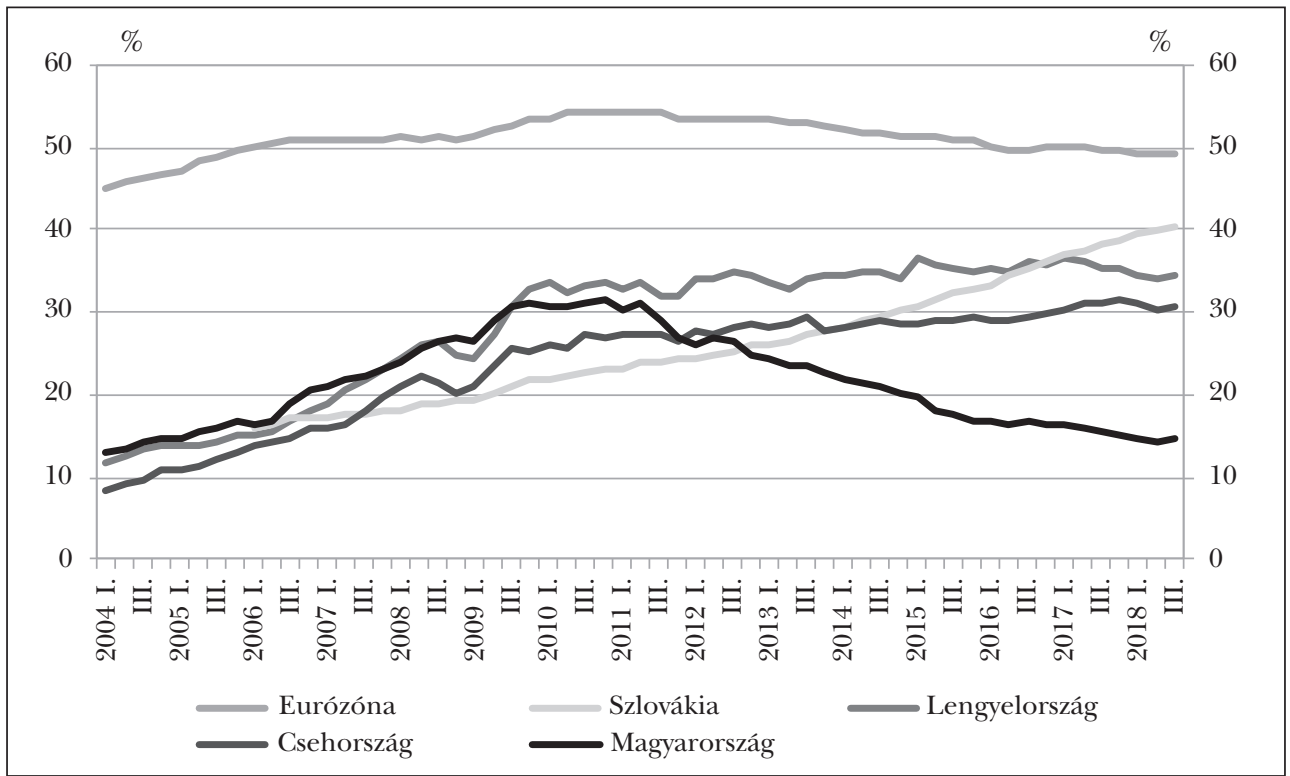

Forrás: $E K B, M N B$

A háztartási hitelezés egészséges bóvülését többek között a 2015-tôl hatályban lévô, a jövedelemarányos törlesztőrészlet és a hitelfedezeti mutató maximumára vonatkozó adósságfékszabályok, valamint a hosszabb távra rögzített kamatozású hitelek új hitelezésben tapasztalható dominanciája biztosítja (MNB, 2019a). Utóbbi folyamatban a Minôsített Fogyasztóbarát Lakáshitel minôsítés bevezetésének is jelentôs szerepe volt, ami a fogyasztók számára kiszámítható hitelfeltételeket biztosított, és a banki ajánlatok könnyebb összehasonlíthatósága révén a versenyt is fokozta. Az MFL-termékek aránya 2018 végére már 60 százalék fölé emelkedett az öt éven túl rögzített kamatozású hite- 
leken belül. Az itt felsorolt szabályok révén a háztartások adósságának növekedése úgy valósulhat meg, hogy az adósságállomány a korábbiakhoz képest több háztartás mérlegében oszlik el, és a gazdasági környezet váratlan változásaira is kevésbé lesz érzékeny.

\section{Devizahiteles fordulat - a devizahitelek csapdája ellen}

A lakossági devizahitelezés a hazai pénzügyi szektor rendszerváltást követô történetének egyik legkárosabb és egyben legköltségesebb epizódjának bizonyult. A devizahitelek makropénzügyi szempontból jelentôs kockázatot hordoztak magukban, ami érdemben növelte hazánk sérülékenységét. A devizahitelek forintosítása ezért kiemelt gazdaságpolitikai cél volt, amely azonban csak 2014-2015-ben valósulhatott meg. Ennek oka, hogy a pénzügyi feszültségektôl mentes konverzióhoz szükséges feltételek fennállása csak ekkorra lett biztosított, amelyek a következók voltak:

- biztos jogszabályi környezet;

- alacsony forintkamatok;

- stabil és konszolidált makrogazdasági környezet;

- rendelkezésre álló szabad devizatartalék.

A konverzióhoz szükséges mintegy 9 milliárd euró devizát a Magyar Nemzeti Bank biztosította a bankok számára, így a forintosítás úgy ment végbe, hogy nem okozott feszültséget a devizapiacon (Kolozsi, 2015). Az MNB továbbá a forintosítással egy időben lezajló elszámolásban is érdemi szerepet vállalt, mind a hitelintézetekre kötelezó módszertan kidolgozása során, mind az intézkedés végrehajtásának ellenôrzése folyamán (MNB, 2016).

19. ábra: A teljes pénzügyi közvetítốrendszer háztartási hitelállománya GDP-arányosan devizanem szerint

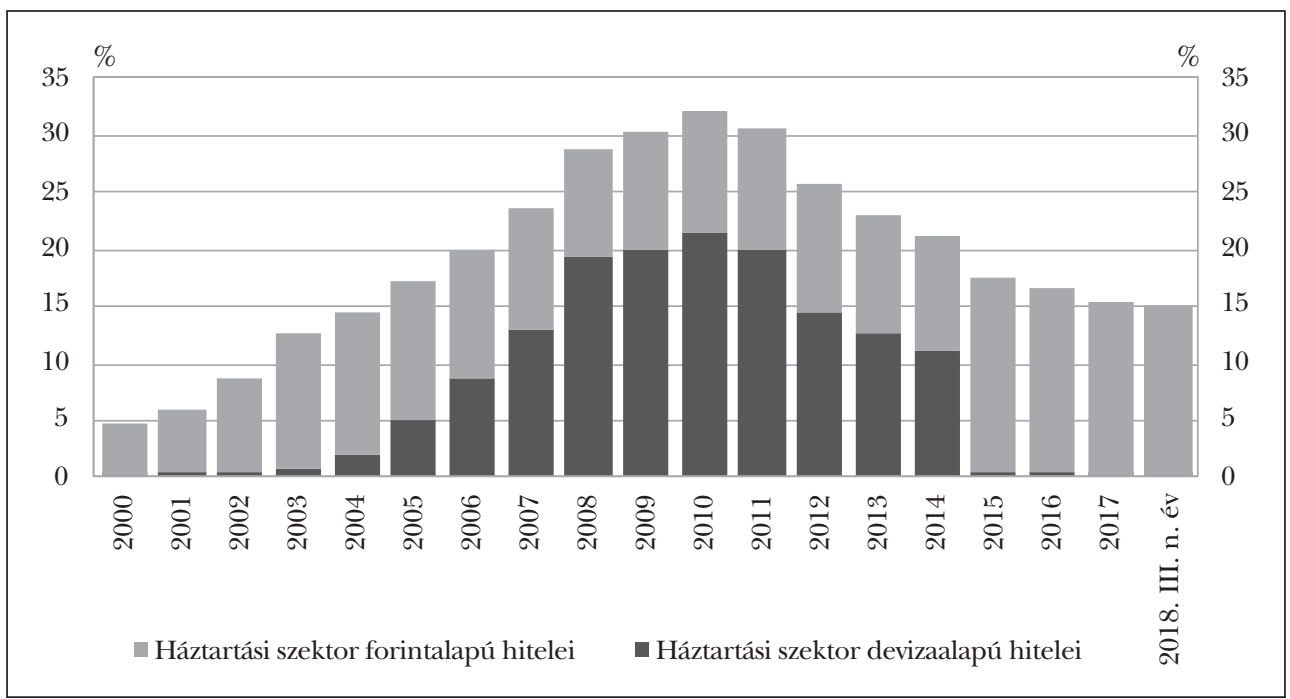

Forrás: $M N B$ 


\section{Matolcsy György: A sikeres válságkezelés a 12 gazdasági fordulat tükrében}

A forintosítás során a kormány, az Országgyúlés, valamint a Magyar Nemzeti Bank között megvalósult gazdaságpolitikai kooperáció révén a devizahitelek jelentette kockázat gyakorlatilag megszúnt. A program időzítését dicséri, hogy az árfolyamok rögzítését követôen alig két hónappal a svájci jegybank elengedte az euróval szemben addig fenntartott árfolyamküszöbét, ami a svájci frank drasztikus felértékelődésével járt. A CHF árfolyama napokon belül a korábbi 250-260 körüli sávból 320 forintra változott, azonban az értékvesztés a nagyobb sérülékenység miatt még ennél is jóval magasabb - akár 70 százalékos (Fábián, 2015) - is lehetett volna, amennyiben a forintosítás technikai értelemben nem történt volna meg már korábban. Az árfolyam hatásán túl pozitív hatást gyakoroltak az MNB monetáris politikai lépései is, hiszen a konverzió idején érvényes 2,1 százalékos BUBOR az azóta eltelt években közel 200 bázispontot mérséklődött, ami a forintosított hitelek kamatlábában is azonnal megjelent. Összességében a konverzió óta eltelt négy évben az adósok jelentôs többletterhektôl szabadultak meg az intézkedéssel. A bankokkal szembeni elszámolások elmaradása, az árfolyamkockázat fennmaradása és a külsố sérülékenység magas szinten ragadása összességében akár 2100 milliárd forinttal is növelhette volna a háztartások kiadásait.

\section{Növekedési és felzárkózási fordulat}

A 2010-et követô gazdaságpolitikai irányváltás egyszerre érintette a növekedés strukturális és finanszírozási feltételeit. A gazdaság számos kulcsfontosságú területén jelentôs mértékú fordulatok következtek be, melyek megalapozták a magyar gazdaság fenntartható növekedési pályára való átállását és a reálgazdasági konvergencia újraindulását.

A válság előtt felhalmozott adósságok miatti elhúzódó mérlegalkalmazkodási kényszer következtében a lakosság fogyasztásában a trendforduló - munkaerôpiaci trendfordulót követóen - 2013-ban következett be. Ehhez jelentős mértékben hozzájárult a 2011 ôszén megkezdett lakossági devizahitel-állomány leépítése, illetve a bevezetett egykulcsos személyi jövedelemadó. Mindezek következtében a háztartások egyre nagyobb mértékben bóvítették fogyasztásukat, ezzel megteremtôdött a hazai gazdasági növekedés alapját adó, erôs belsố kereslet legfontosabb fundamentuma.

A válságot követôen jelentôs változásokat tapasztaltunk a háztartások megtakarítási hajlandóságában. A válság óta a rendelkezésre álló jövedelmek arányában 9 százalék fölé emelkedett a megtakarítási ráta. A lakosság nettó pénzügyi vagyona 2010-et követôen tartós emelkedésnek indult, és az elmúlt években historikusan magas szinteket ért el, miközben a lakosság eladósodottsági mutatója a válság előtti évek szintje alá csökkent. 2010 és 2018 között több mint 25000 milliárd forinttal javult a családok nettó pénzügyi pozíciója: ennek csaknem harmadát a korábbi hitelállomány leépítéséból eredô javulás teszi ki, míg kétharmad részét az aktuális jövedelemból történô pénzügyi befektetés és a meglévő megtakarítások átértékelődése teszi ki. A stabil gazdasági kilátások nyomán erôsödô lakossági bizalom és a kedvezó jövedelmi folyamatok a korábbi idôszakoknál tartósan magasabb megtakarítási ráta fennmaradását eredményezte, ami stabil növekedési pályát és finanszírozási környezetet biztosít a magyar gazdaság számára. 
A hazai növekedés másik fontos pillérét az élénk vállalati hitelezés nyomán erôsödố beruházási alapfolyamatok adják. A jegybank hitelprogramjainak köszönhetôen 2014-ben már beruházási trendforduló is végbement a magyar gazdaságban, a korábbi 16-17 százalékos beruházási rátáról 2018-ra 27 százalék fölé emelkedett a magyar beruházási ráta. A bôvülő beruházások biztosítják Magyarország potenciális növekedési ütemének hosszabb távú emelkedését is.

Gyors növekedést Magyarország korábban csakis a folyó fizetési mérleg hiányának kinyílása mellett, külsố adósságra építve ért el. Az új felzárkózási pályán azonban a gazdaság finanszírozása külsố eladósodás nélkül, döntôen belsô forrásokon alapul. A lakosság magas megtakarítási hajlandósága, a beáramló uniós források és az erôs exportszektor nyomán felhalmozódó külkereskedelmi többlet mind hozzájárult a folyó fizetési mérleg egyenlegének emelkedéséhez. A folyó fizetési mérleg egyenlege összességében immár közel egy évtizede folyamatosan többletet mutat.

A növekedés fenntarthatóságát a külsố adósság szerkezetének átalakulása és szintjének tartós mérséklődése is elôsegítette. A külsố adósság alakulásában bekövetkezett fordulat nyomán 2018 végén a nettó külsô adósságmutatónk a GDP arányában 10 százalék alá süllyedt, és a jelenlegi elôrejelzések szerint 2021 körül elérheti a 0 százalékos értéket, azaz az évtized végétôl a hazai szereplôk több külföldi követeléssel rendelkezhetnek majd, mint amennyi külföldi adósságot törlesztenek.

\section{A monetáris politika összesített hatásai és a 2010 óta bekövetkezố gazdasági fordulatok összegzése}

Összességében a hagyományos és nem hagyományos jegybanki lépések érdemben és átfogóan támogatták a makrogazdaság növekedését. A magyar gazdaság 2013 óta öszszességében 23,1 százalékkal bôvült, amelynek közel felét - 12 százalékot - a monetáris politikai programok adták. Becsléseink szerint a kamatcsökkentés és a jegybanki programok közvetlen módon több mint 6 százalékkal járultak hozzá a GDP-növekedéshez a 2013 és 2018 közötti idôszakban. Ezen belül az NHP program által generált hitelkiáramlás 3,5 százalékponttal, a PHP program 0,9 százalékponttal, míg a kamatcsökkentés 1,7 százalékponttal járult hozzá az idôszak gazdasági növekedéséhez. A jegybanki programoknak azonban számos közvetett hatása is van. A 2013-as évben a gazdaságot a hitelbefagyás (credit crunch) jellemezte, ahol a bankok és a gazdaság többi szereplője közötti bizalomhiány jelentôs akadálya volt az egészséges hitelezés beindulásának. A bizalom helyreállításában és a kkv-piac felélesztésében is érdemi szerepe jutott a jegybanki programoknak. Másrészt a devizahitelek konverziója révén jelentôs veszteségtôl óvta meg a háztartásokat, ezzel hozzájárulva a fogyasztás és a lakossági beruházás fordulatához. Számításaink szerint a közvetett csatornákat is beszámítva, a jegybank közel 12 százalékkal élénkítette a növekedést, ami az idôszak 23,1 százalékos GDP-bôvülésének több mint fele.

Az MNB kamatcsökkentési ciklusának, az Önfinanszírozási programnak és a jegybanki eszköztár átalakításának köszönhetôen jelentôsen csökkentek a hozamok, ami jelentôs megtakarítást jelentett a költségvetésnek, a háztartásoknak és a vállalatoknak 


\section{Matolcsy György: A sikeres válságkezelés a 12 gazdasági fordulat tükrében}

egyaránt. Az állam kamatmegtakarítása 2013 és 2018 között összességében 2400 milliárd forintot tett ki az állampapírpiaci hozamcsökkenés miatt. A vállalatok által a hitelintézeteknek fizetett kamatkiadások összességében 1400 milliárd forinttal csökkentek 2012 óta. A háztartások által a hitelintézeteknek fizetett kamatkiadások összességében 1400 milliárd forinttal mérséklődtek 2012 óta. Az NHP-programok keretében folyósított hitelek 2018 végéig meghaladták a 2800 milliárd forintot. A forintosítás a lakossági adósságterhek emelkedését közel 2100 milliárd forinttal fogta vissza. Így a 2013 óta bevezetett MNB-programok összesen mintegy 10 ezer milliárd forintot juttattak a gazdaságba.

\section{1. táblázat: Az MNB-programok hatása (Mrd Ft)}

\begin{tabular}{l|c}
\hline MNB-programok hatása & $\mathbf{1 0 ~ 1 0 0}$ \\
\hline Növekedés Hitelprogram & 2800 \\
\hline Állami kamatmegtakarítás & 2400 \\
\hline Vállalatok kamatmegtakarítása & 1400 \\
\hline Háztartások kamatmegtakarítása & 1400 \\
\hline Forintosítás & 2100 \\
\hline
\end{tabular}

Forrás: $M N B$

2013-ban újraindult a reálgazdasági konvergencia, ami az Európai Unió tagállamai körében is kiemelkedő növekedéssel párosult, miközben a növekedés szerkezete pedig kiegyensúlyozottá vált. A 2013 óta eltelt 6 évben a hazai GDP-növekedés átlagban 3,5 százalékos volt, míg 2018-ban megközelítette az 5 százalékot. A növekedés ráadásul egy mérsékelt európai konjunktúra mellett következett be, így a hazai GDP dinamikája átlagosan 2 százalékponttal, az idôszak végén 3 százalékponttal haladta meg a fejlett nyugat-európai gazdaságok növekedési ütemét. A 2013 óta tartó növekedési és felzárkózási idôszakot az teszi egyedülállóvá a magyar történelemben, hogy a felzárkózás fenntartható makrofinanszírozási körülmények között valósul meg.

A jegybanki szempontból érdemes megemlíteni - lévén az MNB elsôdleges célja az árstabilitás elérése és fenntartása - az árindex alakulását is. A hazai infláció a gazdasági válságot követôen magas maradt, majd 2013-ban folyamatosan mérséklódött, és a globálisan rendkívül alacsony inflációs környezetben egészen 2016-ig nulla százalék körül alakult. 2017 eleje óta azonban néhány hónapot kivéve szinte folyamatosan a jegybanki toleranciasávon belül alakul, 2018 közepétôl pedig folyamatosan a 3 százalékos cél körül ingadozott az árindex. 2019 elején az adószúrt maginfláció emelkedésével párhuzamosan pedig már kijelenthetô, hogy Magyarországon az infláció az árstabilitásnak megfeleló szinten tartózkodik.

\section{A JöVố KIHÍVÁSAI}

A nemzetközi monetáris politikai és makrogazdasági környezet jelenleg változóban van, a fejlett gazdaságok többségében a gazdasági növekedés érett fázisába ért, a fel- 
20. ábra: Hazai növekedési periódusok

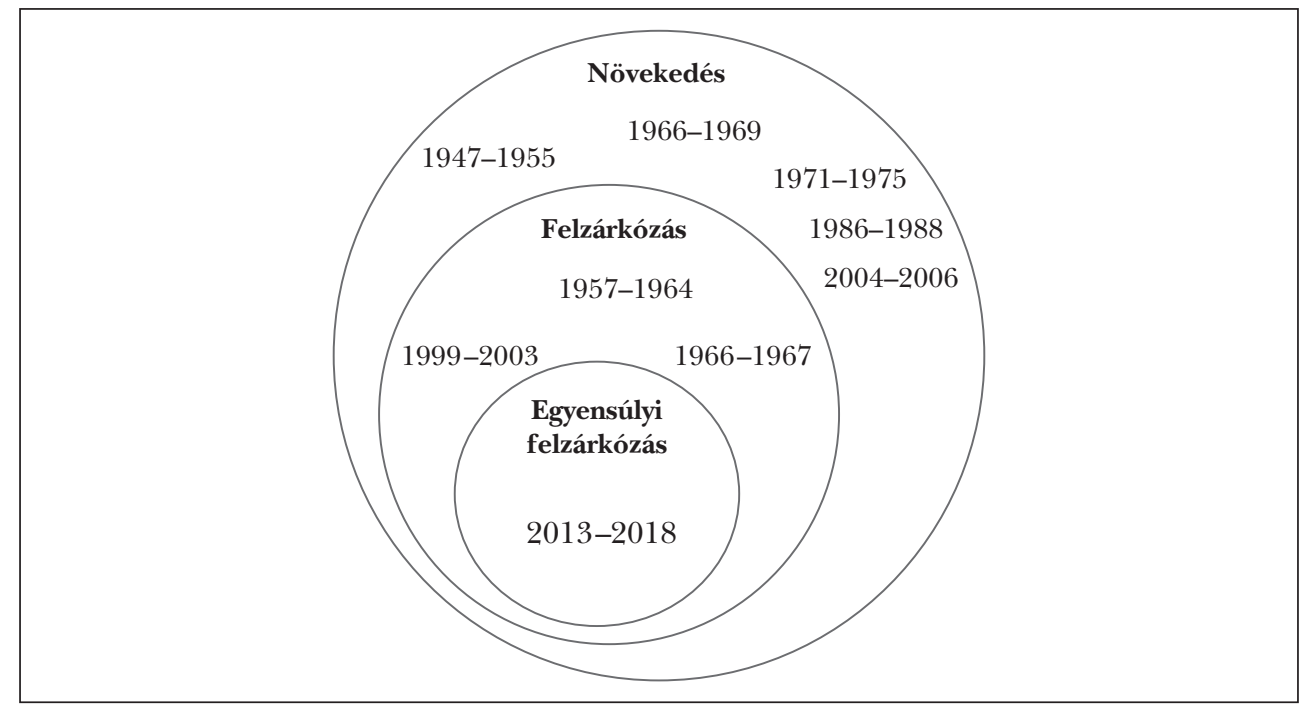

Megjegyzés: Növekedési periódusnak tekintünk minden olyan idôszakot, amely során legalább 1 százalékot elérö reál-GDP-növekedés mutatható ki. További fontos kritérium, hogy a növekedés egymást követố 3 évig tartson. Felzárkózásnak azt tekintettük, amikor Magyarország Ausztriához viszonyított, fix dollárban mért egy före esố fejlettsége közeledett egymáshoz. Itt az olyan idôszakokat vettük figyelembe, ahol legalább 2 egymást követô évben sikerült felzárkózni. Egyensúlyi felzárkózásnak csak azokat az éveket tekintjük, amelyekben a felzárkózás mellett a folyó fizetési mérleg többletet mutatott, illetve a külföldi tartozások mérséklôdése ment végbe. Forrás: Maddison, UNCTADstat, MNB.

21. ábra: Az infláció és az adószürt maginfláció alakulása

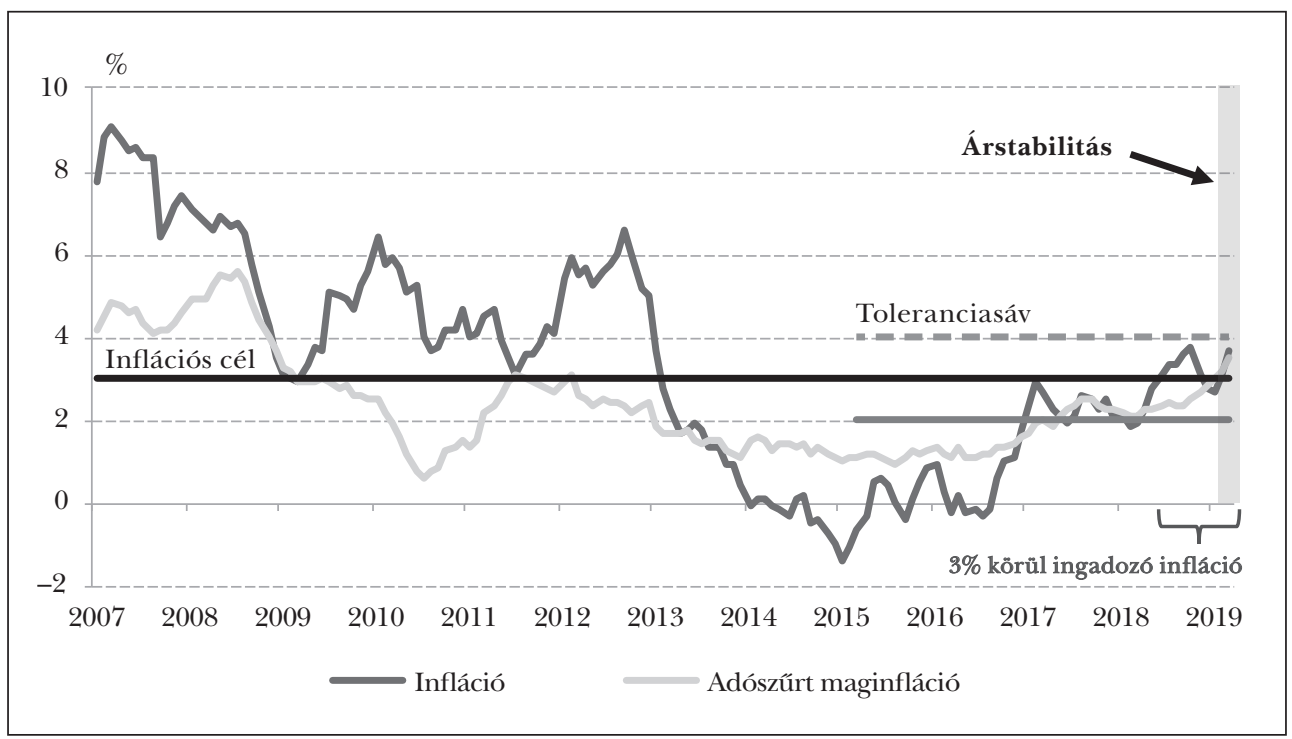

Forrás: $K S H, M N B$ 


\section{Matolcsy György: A sikeres válságkezelés a 12 gazdasági fordulat tükrében}

törekvố piaci tôkeáramlások volatilisabbá váltak, és a jövőbeli gazdasági kilátásokat övezó bizonytalanságok is fokozódtak. Több elemzés is már felveti egy esetlegesen újra bekövetkezô gazdasági válság lehetôségét. Egy Magyarországhoz hasonló felzárkózó, kis, nyitott gazdaság esetében mindez azt jelenti, hogy a gazdaságpolitikának továbbra is törekedni kell az ország sebezhetôségének csökkentésére, a létrehozott védvonalak megerôsítésére, valamint a pénzügyi stabilitás megőrzésére.

Az elmúlt évekre jellemzô felzárkózási ütem hosszú távú fenntartásához a kialakult pozitív trendek megôrzésére és további versenyképességet javító intézkedésekre van szükség. A folyamat tétje, hogy Magyarország ki tud-e törni a közepes fejlettségú országok csoportjából. A gazdaságtörténeti tapasztalatok egyértelmúen mutatják, hogy a felzárkózás nem automatikus folyamat. A gyorsabb növekedést mutató, fejlődó gazdaságok esetében a fejlett régiókhoz képest vett növekedési többlet jellemzôen elôbb fogy el, mint hogy utolérnék a fejlett gazdaságokat.

A sikeres felzárkózáshoz szükséges versenyképességi fordulat lényege, hogy az eddigi fơként extenzív növekedési modellt felváltsa a minôségi feltételekre épülő, tudásés tôkeintenzív növekedési modell. A sikeres felzárkózásnak nincs univerzális receptje. A magas termelékenység, a korszerú technológiák alkalmazása, a magas szintú humán tőke és a kedvezó demográfiai folyamatok ugyanakkor általánosan hozzájárultak a sikeres országok felzárkózásához. A nemzetközi tapasztalatok és a hazai adottságok figyelembevételével Magyarországnak is a saját útját kell járnia versenyképességének erôsítésekor.

A Magyar Nemzeti Bank által 2019 februárjában közzétett Versenyképességi program 330 javaslatának célja a versenyképességi fordulat elérése Magyarországon. A program végrehajtása alkalmas lehet arra, hogy a magyar fejlettségi szint 2030-ra a régió legmagasabb életszínvonalát nyújtó osztrák fejlettség 80-90 százalékára emelkedjen. Ezen lépéseket azonban majd csakis az újabb bó évtized múltán elkészülô tanulmányok értékelhetik.

\section{JEGYZET}

1 A lakossági jelzáloghitelek fedezete mellett bevont forintforrások (pl. jelzáloglevelek, jelzálog fedezete mellett kibocsátott egyéb értékpapírok, jelzálogbanki refinanszírozási hitelek) és az egy éven túli hátralévô lejáratú lakossági forint-jelzáloghitelek nettó állományának hányadosaként számítandó ki konszolidált szinten.

\section{FELHASZNÁLT IRODALOM}

Baksay Gergely - Palotai Dániel (2017): Válságkezelés és gazdasági reformok Magyarországon, 2010-2016. Közgazdasági Szemle, 64. évf., 7-8. sz., 698-722.

Balog Ádám - Matolcsy György - Nagy Márton - Vonnák Balázs (2014): Credit crunch Magyarországon 2009-2013 között: egy hiteltelen korszak vége? Hitelintézeti Szemle, 13. évf., 4. sz., 11-34.

Erhart Szilárd - Kékesi Zsuzsa - Koroknai Péter - Kóczián Balázs - Matolcsy György - Palotai Dániel - Sisak Balázs (2015): A devizahitelezés makrogazdasági hatása és a gazdaságpolitika válasza. In: Devizahitelezés nagy kézikönyve. Nemzeti Közszolgálati és Tankönyvkiadó, Budapest. 


\section{Polgári Szemle $\cdot 15$. évfolyam 1-3. szám}

Fábián Gergely (2015): Mit úsztak meg pontosan a deviza-jelzáloghitelesek? MNB Szakmai cikkek. Megjelent: napigazdasag.hu, 2015. június 6

Kolozsi Pál Péter - Banai Ádám - Vonnák Balázs (2015): A lakossági deviza-jelzáloghitelek kivezetése: idôzítés és keretrendszer. Hitelintézeti Szemle, 14. évf., 3. sz., 60-87.

Matolcsy György (2007): A neoliberális gazdaságpolitika téveszméi. Polgári Szemle, 3. évf., 7-8. sz., 6-16.

Matolcsy György (2008): Harmadik sokkterápia. In: Magyarország politikai évkönyve 2007-ról II. Közpolitika. Demokrácia Kutatások, Budapest, 707-723.

Matolcsy György - Palotai Dániel (2014): Növekedés egyensúlytalanságok nélkül. Fenntartható növekedési pályára állt a magyar gazdaság. Polgári Szemle, 10. évf., 1-2. sz.

Matolcsy György (2015): Egyensúly és nözekedés. Konszolidáció és stabilizáció Magyarországon 2010-2014. Kairosz Kiadó, Budapest.

Matolcsy György - Palotai Dániel (2016): A fiskális és a monetáris politika kölcsönhatása Magyarországon az elmúlt másfél évtizedben. Hitelintézeti Szemle, 15. évf., 2. sz., 5-32.

Matolcsy György - Palotai Dániel (2018): A magyar modell: A válságkezelés magyar receptje a mediterrán út tükrében. Hitelintézeti Szemle, 17. évf. 2. sz., 5-42.

MNB (2015): A Piaci Hitelprogram (PHP) alapösszefüggései és eszközei. MNB, Budapest.

MNB (2016): Félidôs jelentés, 2013-2016. MNB, Budapest.

MNB (2017): A magyar út - Célzott jegybanki politika. MNB, Budapest.

MNB (2018a): A Növekedési Hitelprogram Fix (NHP fix) elindításának jegybanki szempontjai és a konstrukció fontosabb jellemzôi. MNB, Budapest.

MNB (2018b): Pénzügyi stabilitási jelentés (2018. november). MNB, Budapest.

MNB (2019a): Hitelezési folyamatok, 2019. március. MNB, Budapest.

MNB (2019b): Jelentés 2013-2019. MNB, Budapest.

Palotai Dániel (2017): Beértek a 2010-2013 közötti adóreform kedvezó hatásai. MNB Szakmai cikkek, Budapest. 